\title{
Anti-Aging Effects of Calorie Restriction (CR) and CR Mimetics Based on the Senoinflammation Concept
}

\author{
Dae Hyun Kim ${ }^{1}$, EunJin Bang ${ }^{1}$, Hee Jin Jung ${ }^{1}$, Sang Gyun Noh ${ }^{1}$, Byung Pal Yu ${ }^{2}$, \\ Yeon Ja Choi ${ }^{3, *}$ and Hae Young Chung ${ }^{1, *(D)}$ \\ 1 Department of Pharmacy, College of Pharmacy, Pusan National University, 2, Busandaehak-ro 63 beon-gil, \\ Geumjeong-gu, Busan 46241, Korea; bioimmune@hanmail.net (D.H.K.); eunjin2285@gmail.com (E.B.); \\ king2046@hanmail.net (H.J.J.); rskrsk92@naver.com (S.G.N.) \\ 2 Department of Physiology, The University of Texas Health Science Center at San Antonio, \\ San Antonio, TX 78229, USA; yu6936@sbcglobal.net \\ 3 Department of Biopharmaceutical Engineering, Division of Chemistry and Biotechnology, \\ Dongguk University, Gyeongju 38066, Korea \\ * Correspondence: yjchoi@dongguk.ac.kr (Y.J.C.); hyjung@pusan.ac.kr (H.Y.C.); Tel.: +82-51-510-2814 (H.Y.C.)
}

Received: 18 December 2019; Accepted: 3 February 2020; Published: 6 February 2020

\begin{abstract}
Chronic inflammation, a pervasive feature of the aging process, is defined by a continuous, multifarious, low-grade inflammatory response. It is a sustained and systemic phenomenon that aggravates aging and can lead to age-related chronic diseases. In recent years, our understanding of age-related chronic inflammation has advanced through a large number of investigations on aging and calorie restriction (CR). A broader view of age-related inflammation is the concept of senoinflammation, which has an outlook beyond the traditional view, as proposed in our previous work. In this review, we discuss the effects of $\mathrm{CR}$ on multiple phases of proinflammatory networks and inflammatory signaling pathways to elucidate the basic mechanism underlying aging. Based on studies on senoinflammation and CR, we recognized that senescence-associated secretory phenotype (SASP), which mainly comprises cytokines and chemokines, was significantly increased during aging, whereas it was suppressed during CR. Further, we recognized that cellular metabolic pathways were also dysregulated in aging; however, CR mimetics reversed these effects. These results further support and enhance our understanding of the novel concept of senoinflammation, which is related to the metabolic changes that occur in the aging process. Furthermore, a thorough elucidation of the effect of CR on senoinflammation will reveal key insights and allow possible interventions in aging mechanisms, thus contributing to the development of new therapies focused on improving health and longevity.
\end{abstract}

Keywords: aging; calorie restriction; senescence-associated secretory phenotype; senoinflammation; mimetics

\section{Introduction}

The aging process can be defined as progressive, physiological, functional deterioration throughout the lifetime of an individual by different convoluted interactions among genes and non-genetic environmental factors that eventually result in disruption of homeostasis and increased susceptibility to disease or death. The basic mechanism of the aging process is a sustained, long-term inflammatory state that is further aggravated by elevated oxidative stress due to enhanced reactive oxygen species (ROS), lipid peroxidation, and protein oxidative modifications [1]. To understand the phenomenon of aging and its significance, several concepts and terminologies have been proposed including inflammaging, molecular inflammation, micro-inflammation, pan-inflammation, and gero-inflammation. These 
concepts and terminologies are apposite for describing the increased chronic inflammatory events and mediators during aging [2-6].

Generally, cells are continually exposed to and damaged by exogenous and endogenous stress inducers. The cell cycle of damaged cells, which cannot be recovered from cell death, is permanently arrested and the proliferative activity of these cells becomes extinct, which is defined as cellular senescence. This cellular response largely contributes to an organism's aging. Senescent cells have been shown to release multiple inflammatory cytokines and chemokines, which is defined as senescence-associated secretory phenotype (SASP) [7]. An increase in cellular dysregulation due to the release of proinflammatory molecules such as TNF, IL-1 $\beta$, IL-6, MCP-1, MIP- $1 \alpha$, RANTES, and IL-18 $[8,9]$ induces age-related chronic inflammation, leading to aging and its associated diseases.

In order to understand age-related chronic inflammatory progress from a multilayered point of view, we previously proposed a novel concept of senoinflammation, which includes an expanded systemic view of chronic inflammation during the aging process.

$\mathrm{CR}$ is a well-known gold standard for many aging intervention strategies. A number of age-related biological changes and pathologic abnormalities can be delayed or suppressed by CR regardless of gender and species (mammalian or non-mammalian) [10]. CR has been shown to suppress oxidative damage-induced alterations and age-related diseases and to extend lifespan [11]. In this review, we focus on the diverse protective effects of CR against aging from a senoinflammatory perspective. In addition, the beneficial effects of CR mimetics and other types of dietary restrictions on anti-aging are covered.

\section{Age-related Inflammation and Senoinflammation}

Senescent cells produce proinflammatory senescence-associated (SA) secretome, which is referred to as the SASP. Macrophages are recruited in the secretome by chemotactic factors to clear senescent cells [12]. However, senescent macrophages with M2 polarized phenotype secrete proinflammatory cytokines and exhibit impaired phagocytosis and chemotaxis, and a downregulated rate of cellular proliferation [13-15]. It has been proposed that deficiency in the ability of aged macrophages to clear senescent cells leads to increased inflammatory response and results in chronic inflammation as SASP plays a role in the initiation of tissue inflammation [16]. Based on previous observations and evidence of the aging process at molecular and cellular levels, we coined the term "senescent inflammation (senoinflammation)" with a new framework (Figure 1) in our recent review to provide an expanded, broader view of age-related chronic inflammation and metabolic dysfunction [17].

Aging in hepatocytes is associated with various markers of cellular senescence, such as increased expression of heterochromatin protein $1 \beta$, and increased activity of senescence-associated- $\beta$-galactosidase, p21 and p16 [18]. p53 expression is an important marker of cellular senescence and DNA damage in the normal liver [19], and its regulation depends on the nutrient-sensing pathways of non-alcoholic fatty liver disease (NAFLD) [20]. Senescent hepatocytes exhibit increased lipid droplet accumulation and ROS production [21].

In understanding age-related inflammation at the molecular level, an abundance of data in our and other previous work strongly suggested that NF- $\mathrm{KB}$ is a key player involved in the initiation and exacerbation of tissue inflammation in the aging process and cancer [22-24]. Chronic transactivation of NF- $\mathrm{KB}$ has been observed in multiple tissues in various experimental models of aging and human fibroblasts and human CD4+ T cells obtained from aged individuals $[25,26]$. NF- $\mathrm{kB}$ induces proinflammatory mediators, chemokines, and adhesion molecules [27] and interacts with other transcriptional factors that are involved in the initiation and deterioration of chronic inflammatory response including signal transducers, the activator of transcription 3 (STAT3) and p53 [22]. The transcriptional activity of NF- $\mathrm{KB}$ occurs concurrently with crosstalk among upstream signaling components such as glycogen synthase kinase 3 (GSK3)- $\beta$, mitogen-activated protein kinase (MAPK), mammalian target of rapamycin (mTOR), and protein kinase B (PKB) [23,28]. 


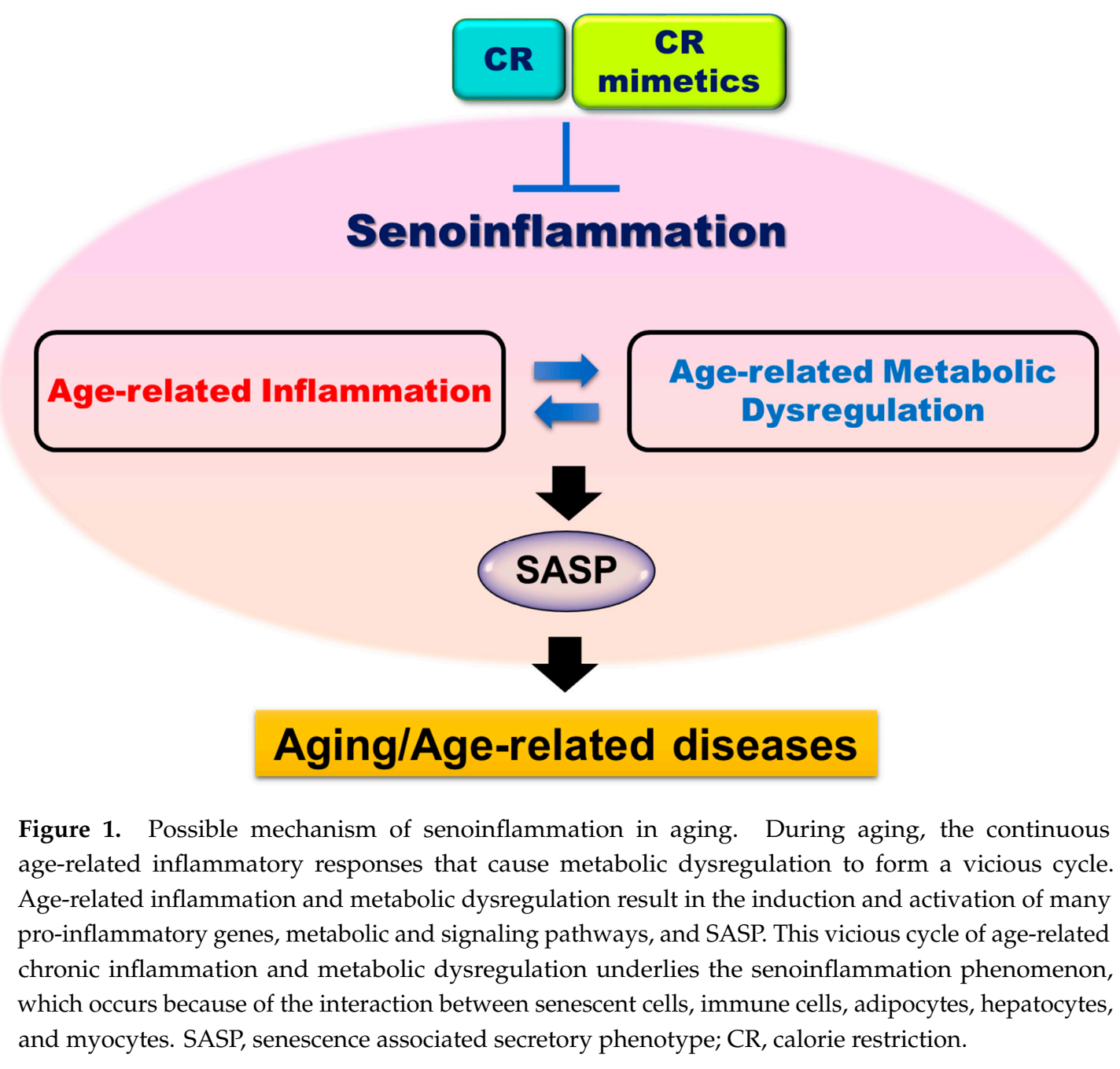

The upregulation of systemic inflammation is associated with aging and age-related chronic diseases [29,30]. As mentioned, age-related systemic inflammation and senoinflammation are functionally distinct from acute inflammatory responses due to sustained high levels of pro-inflammatory mediators. In fact, epidemiological and experimental results suggest that persistent low-grade, chronic inflammation exists in aged animals [31,32]. A recent longitudinal, semi-supercentenarian study in Japan has demonstrated that inflammation, and not telomere length, strongly predicts successful aging at extremely old age [33]. This study concluded that chronic and systemic inflammation has a significant effect on mortality and had a correlation with the decline in cognitive function in the centenarians, thus showing that chronic inflammation is a critical risk factor in the aging process [33]. An increase in systemic inflammation is related to many aging phenotypes. For example, abruptly increased inflammation is generally associated with tissue dysfunction, metabolic syndrome, immune dysfunction, and neuronal complications [34].

$\mathrm{CR}$ animals live fairly longer with the right amount of nutrients, and most of the typical age-related chronic diseases are prevented or delayed in them. For example, the incidence of cancer, the main cause of death in rodents, is significantly reduced in CR animals. Similarly, reduced incidence or slower disease progression has been reported for cardiomyopathy, diabetes, chronic lung diseases, autoimmune diseases, and neurodegenerative diseases $[35,36]$. Preclinical and preliminary clinical studies have shown that $\mathrm{CR}$ or fasting can effectively prevent the development of malignant tumors through a variety of cellular responses and can improve the efficacy of therapeutics [37]. CR reverses most symptoms of immunosenescence, including decreased naïve $\mathrm{T}$ cell and increased memory $\mathrm{T}$ cell population [38], reduced $\mathrm{T}$ cell proliferative response to mitogens or antigens, reduced IL-2 production 
and NK activity [38-42], age-related increase in serum levels of TNF $\alpha$ and IL-6 [43], and autoimmune diseases [44,45]. More recently, CR was shown to delay immunosenescence in animals; however, this effect needs to be confirmed in humans.

Therefore, the concept of senoinflammation shows the orchestral performance of activated pro-inflammatory cytokines and transcription factors at a molecular level, immune cell senescence and SASP at a cellular level, and systemic inflammation and metabolic disorders at a systemic level during the aging process.

\section{Calorie Restriction}

In an initial study on CR by McCay et al. [46], the growth retardation hypothesis was investigated in a rat model by reducing food intake or $\mathrm{CR}$, which slowed down the growth rate and prolonged lifespan. Various additional studies on CR have been conducted in diverse species ranging from yeast, fish, drosophila, hamsters, dogs, and non-human primates to humans [47]. Experts in the field of aging have accepted $\mathrm{CR}$ as an anti-aging experimental concept, which serves as an established aging intervention. As $\mathrm{CR}$ is a non-genetic, nutritional means to delay the aging process, it was used to identify underlying signaling mechanisms of aging, resulting in its considerable importance. Understanding elemental mechanisms underlying the effect of $\mathrm{CR}$ is critical as they may aid in identifying novel therapeutic molecular targets for age-associated inflammatory pathological conditions.

Previous studies conducted at the molecular level significantly support the hypothesis that $C R$ is capable of reducing age-associated oxidative stress and suppressing systemic, chronic inflammation [48]. $\mathrm{CR}$ and its anti-aging effects are majorly considered due to its significant regulatory role in oxidative stress and capability to sustain appropriate cellular redox conditions [1]. CR also has beneficial effects in the inhibition of protein synthesis and the oxidization of proteins in the liver and skeletal muscle. Furthermore, it enhances immune functions and inhibits inflammatory responses during the aging process [49]. CR exerts preventive or delaying effects on age-associated diseases, such as chronic nephropathies, cardiomyopathies, diabetes, autoimmune conditions and respiratory diseases, as well as aging [48,50]. Implementation of CR in mice suppressed the degree of neurological degeneration and $\beta$-amyloid deposition in the brain tissue and subsequently promoted the generation of neurons in in vivo animal models of Alzheimer, Parkinson, and Huntington diseases [51,52]. The results of the first randomized clinical human trial on CR highlighted a reduced probability of developing age-related diseases and improved number of biomarkers showing health longevity.

\section{Anti-senoinflammatory Effect of CR}

Many interventions and strategies for modulating chronic inflammation and anti-aging have been scientifically demonstrated. Among many well-described anti-aging strategies, CR has been identified as one of the most powerful interventions to fight the aging process and age-related pathological conditions such as diabetes, obesity, cardiovascular diseases, rheumatoid arthritis, Alzheimer's disease and more [53]. Although the detailed molecular mechanisms and signaling pathways underlying CR still require further investigation, previous evidence for modulatory action of $\mathrm{CR}$ in senoinflammation suggest potential therapeutic effects of CR on aging (Table 1). For example, at a molecular level, CR exhibits powerful anti-inflammatory effects by suppressing key pro-inflammatory mediators such as NF-kB, IL-1 $\beta$, IL-6, TNF, cyclooxygenase 2 (COX-2), and inducible nitric oxide synthase (iNOS) [54-56]. In addition, $\mathrm{CR}$ was shown to regulate the activity of pro-inflammatory upstream signaling pathway molecules such as MAPKs (ERK, JNK, p38), and NIK/IKKs. CR was also shown to regulate the DNA binding activity of NF- $\mathrm{KB}$ and AP-1 transcription factors and expression of their corresponding genes, COX-1 and iNOS [55,57]. CR was also shown to reduce the plasma concentration of cytokines, TNF, ICAM-1 and to induce cortisol release, which suppresses the systemic inflammatory response [58,59]. In obese mice models, implementation of $30 \%$ CR for 2 months notably decreased the levels of adipose tissue cytokines and chemokines, including IL-6, IL-2, IL-1R $\alpha$, MCP-1, and CXCL16, which are considered as major components of SASP [60]. In hepatic tissue, even mild CR notably suppressed 
proinflammatory and lipogenic gene expression of molecules such as MCP-1, SREBPs, and peroxisome proliferator-activated receptor (PPAR)- $\gamma$ [61]. These evidences suggest that CR successfully regulates the symptomatic prevalence of senoinflammation that expands to pathological conditions such as chronic inflammation, insulin resistance, and low energy metabolism [17,58,62,63].

Regarding anti-aging effects, CR is known to play an important role in suppressing oxidative stress and damage $[64,65]$. Cellular oxidative stress leads to formation of ROS, hydrogen peroxide, reactive nitrogen species, peroxynitrites, which then induce cellular inflammation, damage, and senescence. CR exerts its beneficial, maximal life-spanning effects by partially attenuating oxidative stress. For example, age-dependent functional decline of mitochondria in cardiac tissue, a major organelle of ROS production, has been well documented. Additionally, it was demonstrated that CR attenuates oxidative damage in an aged heart by lowering the levels of 8-oxodG, an oxidative damage DNA biomarker [66].

In addition to the anti-inflammatory effects described above, $\mathrm{CR}$ is also well known for regulating the expression of various genes involved in regulating energy metabolism. In regulating lipid metabolism, the PPARs could sense fatty acid molecules released from dietary lipids and their metabolites. PPARs are specialized receptors that recognize and bind lipid metabolites to transmit signals and can regulate lipid and carbohydrate metabolisms and inflammation. Among three subtypes of PPARs, PPAR $\alpha$ and PPAR $\gamma$ have been well investigated and both have been suggested as regulators of inflammatory responses. In an aged rat model, the expression of PPAR $\alpha$ and PPAR $\gamma$ genes was decreased and age-associated alterations were reversed by CR [63,67]. In a previous review, it has

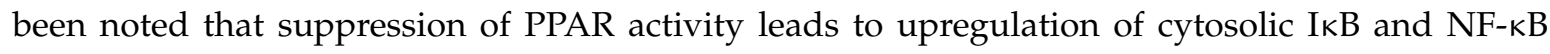
inhibitor, and suppression of NF- $\mathrm{kB}$ activation [68]. Such experimental evidence further strengthens the fact that PPAR $\alpha$ agonists could alleviate age-related inflammation by suppressing NF-kB-mediated proinflammatory cytokine production $[67,69]$.

CR modulates nutrient-signaling pathway molecules such as sirtuin proteins. One major molecule known to exert its effects in delaying aging and increasing longevity during CR is SIRT1 [70]. Sirtuins regulate protein expression in diverse cellular processes such as DNA repair, epigenetic modification of chromatin, ROS production, and metabolism. CR is well known to promote SIRT expression and activation in the liver, adipose tissue, brain and kidney by interacting with FOXOs, PGC1 $1 \alpha$, p53 and NF- $K B$ to mediate anti-aging effects [71]. CR-mediated SIRT1 activity regulates pro-inflammatory NF- $\mathrm{kB}$ activation. For example, SIRT1 induces deacetylation and suppresses NF- $\mathrm{kB}$ activation [72,73].

Diverse research has provided an understanding of the association between aging and $C R$ and the effects of CR on senoinflammatory and metabolic signaling pathways. The experimental evidence suggests that $\mathrm{CR}$ exerts beneficial effects on senoinflammation during aging by altering molecular pathways through regulation of expression and activities of core molecules such as NF- $\mathrm{kB}$, PPARs, SIRT1, and others. Collective evidence on CR further supports the concept of senoinflammation during the aging process and confirms the positive role of CR against aging. In addition, the evidence strongly supports the notion that the anti-aging effects of $C R$ are due to the alleviation of systematic physiological senoinflammatory response. However, further research is needed to clearly define the signaling mechanisms in detail.

\section{Omics Big Data on Aging and CR}

The immense amount of collected data in the field of biology and biomedicine research necessitates integrative data analysis to understand a complicated physiological system as a whole. Integrative dataset analysis has also provided an understanding of the underlying mechanism of aging and age-dependent changes at molecular, cellular, and physiological levels. An immense amount of data on age-related diseases enables the building of interactive networks and alterations in these networks may aid in developing aging intervention methods. Transcriptomics is the study of complete sets of RNA transcripts of a whole genome under certain conditions, which includes analysis of comparative differential gene expression in response to different conditions. As the biological aging process is 
complex and heterogeneous, defining specific mechanism of aging and a potential intervention method such as CR requires data integrative analysis based on age-dependent changes at the molecular level.

Among Omics Big Data analysis, gene set enrichment analysis (GSEA) allows the identification of gene types that are significantly associated with the disease. In order to analyze young and aged groups, RNA-sequencing data were collected and analyzed by the GSEA method to detect the set of differentially expressed genes or DEGs. Based on the results, it was demonstrated that proinflammatory functional genes, including cytokines, chemokines, TNF and toll-like receptors (TLRs), were notably over-represented in the aged group, whereas genes associated with metabolism, such as fatty acid metabolism and PPAR pathways, were significantly suppressed. This suggests that aging is highly associated with gene expression alterations including increased expression of inflammatory genes and decreased expression of metabolic genes. In addition, it was found that these changes were reversed by $C R$, a well-known aging intervention method [74].

By detecting DEGs, the Omics Big Data analysis method can identify informative epigenetic modifications along with the changes in gene expression and potential biomarkers of aging and age-related pathologic conditions. The results of a previous epigenetic study, performed using collective genomic data program called The Cancer Genome Atlas (TCGA) Program, indicated various age-related changes in the pattern of DNA hypomethylation in young and old subjects. In particular, the genes that were upregulated and hypomethylated were AZU1, ELF3, NOX1, IL1B, and S100A12; these genes are known to function in inflammatory responses, indicating that inflammatory genes are involved in age-related cancer onset and progression [75]. A previous briefing paper discussed the idea of big data in the field of medicine and suggested that a big network constructed by multi-omics data such as epigenomics, transcriptomics, and metabolomics can detect a significant association existing between aging and inflammation, indicating the use of a systems biology tool to identify new genes involved in inflammaging [76].

Omics Big Data is a useful tool to investigate the beneficial effects of CR. The transcriptome profile of mice liver tissue obtained after implementation of CR showed that CR improved the expression of genes associated with health, which were previously modulated by obesity. These data and other research studies collectively indicate that CR promotes beneficial outcomes leading to the expansion of life span [77]. In another study, transcriptomic data of adipose tissue indicated that CR suppresses transcription and activity of genes involved in inflammatory response, for example, the NF- $\kappa \mathrm{B}$ signaling molecule gene. Additionally, in that study, diverse evidence indicated that CR has protective effects in physiological systems [78]. Furthermore, based on a global mass spectrometry-based metabolomics study, graded CR $(10,20,30,40 \%$ CR) modulated metabolic signaling pathways, including the carnitine synthesis and shuttle pathway and sphingosine-1-phosphate and methionine metabolism, in a graded manner. The expression of various metabolites was modulated by CR, indicating that CR could ameliorate the energy release process of hepatic fatty acids [79]. In addition, augmented gene-gene network connectivity analysis has shown that CR changed the network arrangement and biological gene centrality in a CR level-dependent manner. Therefore, the results suggested that CR-induced genes play a critical role in countering the age-associated loss of gene-gene network connectivity [80]. In order to better understand the mechanism of CR in age-associated pathological symptoms, its relation to insulin sensitivity has also been investigated. Multi-omics approaches that integrate transcriptomics, metabolomics, and microbiomics data were used to further enhance our previous knowledge that CR induced amelioration of insulin sensitivity and lifestyle, gut microbiome, and extrinsic environmental factors. Furthermore, it identified potential biomarkers that could be used for personalized weight-loss interventions [81].

Analysis of transcriptomic data from different tissues shows that aging induces the upregulation of inflammatory pathways and downregulation of metabolic pathways. In contrast, CR intervention reverses such effects, in which it downregulates the immune response and upregulates the metabolic pathways. In particular, LCK, a key signaling molecule in the development of T cells, was significantly upregulated in aged tissues and later downregulated as a consequence of CR. This identification of 
LCK gene was based on integrative analysis of cDNA microarray and interactome, which showed a high degree of centrality and between centrality analyses. These results suggest that immune and inflammatory responses are increased during aging and can be modulated by CR [82]. In support of such results, Hong et al. reported that CR successfully suppressed immune response and increased lipid metabolism, thereby delaying aging and preventing age-associated diseases [83]. Kim et al. also reported that CR implementation delayed age-associated alterations of DNA methylation, which could prevent the progression of age-related diseases [84].

Other omics studies provided evidence that CR definitively modulates aging processes and prevents or delays age-associated disease progression. Analysis of hepatic transcriptome showed that CR stimulated pathways involving IGF-1, NF- $\mathrm{kB}, \mathrm{mTOR}$, and SIRTs, which collectively contribute to reduced oxidative stress and improved metabolism, further supporting that CR promotes health and could extend lifespan by interfering with age-associated signaling pathways [85]. In addition, CR suppresses adiposity and insulin resistance, consequentially suppressing a proinflammatory status. By implementing CR, DEG analysis could help identify biomarkers that are closely related to age-associated diseases, including metabolic disease [86]. In support of the beneficial effects of CR in aging, one of the proteomics analyses demonstrated that CR improved glucose and lipid energy metabolism and suppressed oxidative stress [87]. As lipid composition was one of the critical determinants of aging, using CR as an intervention method, a research group conducted LC-MS and demonstrated that $C R$ reprogrammed the lipidome and metabolome, which lowered the protein oxidative damage, sequentially increasing lifespan and healthspan [88].

\section{Preventive Effects of Other Types of Dietary Restriction in Aging}

$\mathrm{CR}$ is usually considered for reducing overall calorie intake or food intake without malnutrition. In animal models, under CR, food intake is reduced by around 10-50\% compared with ad libitum-fed controls [89]. Although CR exhibits preventive effects on age-related phenotypes, to practice and sustain CR in human life is quite challenging. In efforts to improve human health during aging, there are other types of dietary restriction and pharmacological interventions available that mimic CR. Here, we introduce other types of dietary restriction and CR mimetics, recapturing the beneficial effects of $\mathrm{CR}$ in the present and next sections.

Reduced intake of specific nutrients, rather than reduced intake of total calories, was considered important for health benefits of a restricted diet. The reduction of either dietary protein or sugar can reduce mortality and extend life span in Drosophila, independent of the calorie intake [90]. A study by Solon-Biet et al. in mice showed a clear correlation between the ratio of protein to carbohydrate and lifespan. Mice were fed 25 diets differing systematically in protein, carbohydrate, and fat content. The energy density and median lifespan of the mice increased by up to $30 \%$ as the protein to carbohydrate ratio decreased [91]. In addition, it is suggested that reduced intake of specific essential amino acids such as methionine, tryptophan, or branched chain amino acids can delay aging or improve health $[92,93]$.

Intermittent (ex. alternate day fasting) and periodic (fasting that lasts three days or longer, every two or more weeks) fasting have been studied as alternative dietary interventions for long-term CR [94]. The effects of fasting on lifespan extension have been reported in various species including bacteria [95], yeast [96], worm [97], and mice [98]. Intermittent fasting has a protective effect on age-dependent diseases including diabetes, cancer, heart disease, and neurodegenerative disorders in rodents [94]. There are various regimens of fasting. Recently, the fasting mimicking diet (FMD) was developed and has shown several beneficial effects in mice including extended longevity, lowered visceral fat, reduced cancer incidence and skin lesions, rejuvenated immune system, and retarded bone mineral and hippocampal neurogenesis [99]. 


\section{CR Mimetics in Aging}

$\mathrm{CR}$ mimetics are compounds that mimic the benefits of $\mathrm{CR}$ at the molecular, cellular, and physiological levels, leading to health-promoting effects [100]. Recently, there has been an increased interest in CR mimetics due to the benefits of using these anti-aging interventions in terms of extended health and lifespan [101-103]. Although the valuable effects of CR mimetics on lifespan and health have been extensively highlighted, limitations persist because it is difficult to implement such diet regimens in humans. In this section, we summarize the current knowledge of CR mimetic compounds and highlight their typical effects.

\subsection{Resveratrol}

Resveratrol (3,5,4'-Trihydroxystilbene), a natural polyphenolic, phytoalexin compound found in grapes, cranberries, and peanuts, is currently the most thoroughly studied CR mimetic. Resveratrol promotes lifespan extension across a range of evolutionarily distinct sets of species, including Saccharomyces cerevisiae, Caenorhabditis elegans, and Drosophila melanogaster, all the way to mammals such as mice [104]. Previous studies have indicated the beneficial effects of sirtuins as the best small molecule that activate sirtuins, which extended lifespan in a yeast model [104-109]. Although only the longevity extension effect of resveratrol has been reported in C. elegans and D. melanogaster, many subsequent studies reported that resveratrol intake promotes health and plays a preventive role in age-related diseases, such as cancer [110-113], atherosclerosis [114,115], arthritis [116,117], cataract [118-120], cardiovascular disease [121], hypertension [122,123], type 2 diabetes [124-127], osteoporosis [128-130], and Alzheimer disease [131-133]. In clinical studies, resveratrol intake improved the memory capacity of elderly individuals and reduced blood lipid levels in obese and type 2 diabetic patients $[134,135]$. However, additional studies are required to investigate intake duration and dose-dependent metabolic effects of resveratrol supplements required to overcome metabolic irregularity in human subjects. Resveratrol suppresses SASP through SIRT1/NF- $\mathrm{KB}$ signaling and delays aging [136], represses cellular senescence, and improves insulin resistance in muscle [137].

\subsection{Metformin}

Metformin, a biguanide used as a first-line drug for treating type 2 diabetes [138], was shown to extend the lifespan of C. elegans [139-141], D. melanogaster [142], and mice [143,144]. Moreover, it was shown to delay the onset of age-related diseases, such as cancer, metabolic syndrome [145], and cognitive disorders [146]. Its mechanism of action is associated with the activation of 5' AMP-activated protein kinase (AMPK) $[147,148]$, inhibition of the mammalian target of rapamycin (mTOR) [149], reduction of DNA damage [150,151], and decreased insulin levels and IGF-1 signaling [152-154]. The longevity effect of metformin has not yet been identified in humans, and therefore, its mechanism of action requires further investigation. Metformin regulates mitochondrial biogenesis and cellular senescence through SIRT3 [155], and decreases oxidative stress-induced senescence by activating autophagy [156].

\subsection{Rapamycin}

Rapamycin, (International Nonproprietary Name: sirolimus), is an inhibitor of mTOR, which results in an extended life span and prevents age-related diseases [157-160] by mediating SIRT1 expression [161,162]. mTOR is a serine-threonine kinase that plays a role in modulating cell survival, growth, proliferation, motility, protein synthesis and transcription [163] and inducing autophagy [164-166]. In addition, mTOR promotes growth and aging in C. elegans [167], D. melanogaster [168], S. cerevisiae [169], as well as in mice [170,171] and rat $[172,173]$ models. Further, it modulates glucose and lipid metabolism $[174,175]$. Rapamycin prevents insulin resistance in humans [176], reduces insulin resistance in hyperinsulinemia rats [177,178], and normalizes glucose metabolism in diabetic mice $[179,180]$. Recently, Garcia et al. [181] reported that rapamycin treatment 
has a mechanism similar to CR in ovarian mice, which increases FOXO3 gene expression. Thus, the use of rapamycin as a CR mimetic needs to be investigated further for understanding significant signaling pathways that can be targeted for enhancing its therapeutic potential. Rapamycin ameliorates age-related late-life cancer by inhibiting senescence-associated inflammation [182]. It is also an effective inhibitor of cellular senescence [183].

\subsection{PPAR Agonists}

In addition to the anti-inflammatory effect, PPARs have diverse biological effects including the promotion of cellular proliferation, glucose and lipid metabolism, insulin sensitivity, and tissue remodeling processes $[67,184]$. Because of their association with multiple metabolic processes, PPARs have been suggested to play roles in pathogenic conditions such as obesity, metabolic syndrome, diabetes, NAFLD, and atherosclerosis. Therefore, PPARs have been considered as important molecular targets for the discovery and development of new drugs to treat these age-related diseases [185-188].

Fenofibrate is a PPAR $\alpha$ agonist used for the treatment of hyperlipidemia, hyperglycemia, and hypertriglyceridemia $[189,190]$. PPAR $\alpha$ activation by fenofibrate also reduces renal oxidative stress and cellular apoptosis in aging-related renal injury through AMPK-SIRT1 and AMPK-PGC1 $\alpha$ signaling pathways [191]. The activation of PPAR $\alpha$, AMPK, and SIRT1 has been shown to protect aging-related renal injury. PPAR $\beta / \delta$ is involved in the regulation of insulin sensitivity, adipogenesis, lipid and energy metabolism, inflammation, and atherosclerosis [192-194]. A specific PPAR $\beta / \delta$ agonist, GW501516, attenuates inflammation, insulin resistance, and dyslipidemia, and modulates angiogenesis [192,193]. Two thiazolidinediones (TZD), rosiglitazone and pioglitazone, which are also PPAR $\gamma$ agonists, have been shown to be effective in the treatment of type 2 diabetes $[195,196]$. Further, they are also associated with human life longevity and cell senescence [197]; this has also been observed in aged rats [198]. Recently, Patel et al. [199-201] reported that a novel dual PPAR $\alpha / \gamma$ agonist, saroglitazar magnesium, was used in the treatment of dyslipidemia and metabolic disorders in in vivo and healthy Indian adult subjects. These results are further supported by the results of a preclinical study conducted by Kaul et al. [201]. Notably, Xu et al. [202] reported that chiglitazar acts as a PPAR- $\alpha / \beta / \gamma$ pan agonist and evaluated its use in diabetic therapeutics in healthy Chinese volunteers.

Recent data support PPAR agonists as potential candidates for anti-senoinflammation therapy. Our group synthesized MHY908, new a PPAR $\alpha / \gamma$ dual agonist, and showed that it has a significant inhibitory effect on age-related inflammation and insulin resistance [203]. It is reported that PPAR activation might have an effect on the prevention of cell senescence and that PPAR $\alpha$ silencing induces cancer cell senescence. Rosiglitazone significantly suppressed olaparib (a PARP inhibitor)-induced cellular senescence and SASP in ovarian cancer [204].

Collectively, identifying the role of PPAR agonists in various metabolic or non-metabolic organs and pathological conditions will contribute to the development of new therapeutic options and promising anti-senoinflammatory chemicals for the treatment of many age-related metabolic disorders.

\subsection{Ketone Bodies}

Ketone bodies such as $\beta$-hydroxybutyrate (HB), acetoacetate, and acetone are water-soluble molecules that are generated from fatty acids in the mitochondrial matrix of the liver. They serve as moving energy sources for physiological systems during periods of fasting [205]. The process of ketogenesis starts within $24 \mathrm{~h}$ of fasting through gluconeogenesis [206]. In humans, physiological serum levels of HB are normally maintained at a low micromolar concentration, which increases to a few hundred micromoles after 12 to $16 \mathrm{~h}$ of the fasting period and eventually reaches 1 to $2 \mathrm{mM}$ after 2 days of fasting [207]. Insulin inhibits lipolysis of adipose tissue and restricts ketogenesis, while glucagon promotes ketogenic flow by exerting its direct effect on the hepatic tissue [208]. In a study, CR or fasting interventions elevated the circulating concentration of ketone bodies, $\mathrm{HB}$, compared to that in a normal feeding group $[209,210]$. Furthermore, it has also been reported that the implementation of 
a ketogenic diet exerts therapeutic effects on various age-related diseases related to insulin resistance, as well as diseases resulting from free radical damage and hypoxia [211].

$\mathrm{HB}$ also acts as a signaling molecule and activates cellular signaling pathways. For example, HB plays a role in endogenously inhibiting histone deacetylases (HDACs) [209]. Suppression of HDAC activity exerts beneficial metabolic and cytoprotective effects similar to those seen in $\mathrm{HB}$ investigations [212]. However, SIRT3 regulates diverse pathways involved in fasting metabolism, and mice without SIRT3 genes have decreased HB concentration during fasting [188]. Ketogenic diets are also related to low levels of insulin [213,214], suppressed IGF signaling [215], induction of FOXO3 [209], and activation of AMPK $[215,216]$ and antioxidant genes [209]. Ketone bodies exert neuroprotective and lifespan extension effects similar to CR in C. elegans [217]. HB upregulates transcription of antioxidant genes, including manganese superoxide dismutase (MnSOD) and FOXO3, both of which exert antioxidant effects [209]. It is thought that HB exerts its effect through signaling mechanisms comparable to that of CR by inducing co-activation of FOXO1/PGC-1 $\alpha$ through deactivation of the PI3K/Akt pathway [218].

HB is an effector that transduces signals via G-protein coupled receptors. It represses the actions of the sympathetic nervous system and decreases energy expenditure and heart rate by blocking fatty acid signaling pathways through the G protein-coupled receptor 41 [219]. One of the most well-studied signaling effects of HB signals is via GPR109A, a member of the hydrocarboxylic acid GPCR subfamily that is expressed in adipose tissues (white and brown) [220] and immune cells [221]. Although the GPR109A receptor has protective effects, associations have been found between ketogenic dietary intervention use in stroke patients and neurodegenerative diseases [222,223]. In a TNF $\alpha$ or LPS-induced inflammatory setting, HB exerts anti-inflammatory effects by suppressing the release of pro-inflammatory proteins (iNOS and COX-2) and cytokines (TNF, IL-1 $\beta$, IL-6 and CCL2/MCP-1), which seems to occur partially via inhibition of NF- $\mathrm{B}$ translocation to the nucleus for pro-inflammatory gene activation [224,225]. However, in neurodegenerative inflammatory conditions, the effects of GPR109A-mediated HB do not appear to involve inflammatory mediator signaling via the MAPK pathway [224]. In addition to their role in providing energy fuels for various key organs and tissues, including the brain, heart or skeletal muscle, ketone bodies play critical roles as signaling mediators and modulators of inflammation and oxidation [226].

\section{Conclusions}

Based on the available molecular and biochemical evidence, we proposed the concept of senoinflammation in our previous review [17,227]. The concept proposes a broader perspective on age-related inflammatory response and creates a complex network among many inflammatory mediators that can lead to systemic chronic inflammation. Oxidative stress leads to improper gene regulation and genomic DNA damage during aging. Such improper gene regulation in aged senescent cells allows them to fall into a proinflammatory state, consequently changing systemic chemokine or cytokine activities. The proinflammatory SASP environment further exerts stress on the intracellular organelles, tissues, and systems, which affects the development and occurrence of metabolic disorders. It appears that a repetitive vicious cycle occurs between SASP and metabolic dysregulation as proposed in the concept of senoinflammation, and this interactive network forms the basis of the aging process and age-related diseases. However, the secretion of proinflammatory mediators, collectively termed as SASP, in response to internal and external stress leads to the chronic inflammatory condition termed as senoinflammation. Based on CR experiments and observations, cytokine, chemokine, and metabolic pathways are significantly regulated by CR and CR mimetics in the aging process. It is expected that a better understanding of senoinflammation modulatory mechanisms will provide a basis for the discovery of molecular targets that can therapeutically modulate age-related chronic inflammatory conditions and enable the development of potentially effective interventions to delay aging and prevent the occurrence of aging-associated diseases. 
Table 1. Changes in parameters in senoinflammation.

\begin{tabular}{|c|c|c|c|c|c|}
\hline & SASP Factors & Old & CR & Species & References \\
\hline \multirow{9}{*}{ Cytokines } & IL-1 $\beta$ & $\uparrow$ & $\vdash$ & Human, Mouse, Rat & {$[82,228-230]$} \\
\hline & IL-6 & $\uparrow$ & $\vdash$ & $\begin{array}{l}\text { Human *, Mouse, } \\
\text { Monkey }\end{array}$ & {$[82,231-233]$} \\
\hline & IL-7 & $\uparrow$ & & Human, Rat & {$[74,82]$, TCGA database } \\
\hline & IL-13 & - & & Human & TCGA database \\
\hline & IL-11 & $\uparrow$ & & Rat & {$[74,82]$} \\
\hline & IL-6R & $\uparrow$ & & Rat & {$[74,82]$} \\
\hline & IL-2RA & $\uparrow$ & & Rat & {$[74,82]$} \\
\hline & TNF- $\alpha$ & $\uparrow$ & $\vdash$ & C. elegans, Mouse, Rat & {$[74,82,231,234]$} \\
\hline & TNF- $\beta$ & $\uparrow$ & & Human, Rat & {$[74,82]$, TCGA database } \\
\hline \multirow{5}{*}{ Cheomokines } & IL-8 & $\uparrow$ & $\vdash$ & Monkey & [235] \\
\hline & MCP-1 (CCL2) & $\uparrow$ & $r$ & Mouse, Rat & {$[74,82,236]$} \\
\hline & MCP-2 & - & $\vdash$ & Mouse & [237] \\
\hline & MIP-1 $\alpha$ (CCL3) & - & F & Mouse & {$[236,238]$} \\
\hline & MIP-3 $\alpha$ & $\uparrow$ & & Rat & {$[74,82]$} \\
\hline \multirow{11}{*}{ MMPs, GFs, etc. } & MMP1 & $\uparrow$ & & Human, Mouse & {$[239,240]$} \\
\hline & MMP2 & $\uparrow$ & $r$ & Mouse & [241] \\
\hline & MMP3 & $\uparrow$ & $r$ & Mouse, Rat & {$[60,74,82,242]$} \\
\hline & MMP9 & $\uparrow$ & $\vdash$ & Mouse, Rat & {$[243,244]$} \\
\hline & MMP12 & $\uparrow$ & & Rat & {$[74,82]$} \\
\hline & MMP13 & $\uparrow$ & $r$ & Rat & [245] \\
\hline & MMP14 & $\uparrow$ & & Human & TCGA database \\
\hline & HGF & $\uparrow$ & & Human, Rat & {$[74,82]$, TCGA database } \\
\hline & EGFR & $\uparrow$ & & Human, Rat & {$[74,82]$, TCGA database } \\
\hline & FAS & $\uparrow$ & $\vdash$ & Human, Mouse, Rat & {$[74,82,246-248]$} \\
\hline & IGFBP2 & $\uparrow$ & & Human & TCGA data base \\
\hline \multirow{4}{*}{ Metabolism } & Insulin resistance & $\uparrow$ & $r$ & Human, Mouse, Rat & {$[181,249-251]$} \\
\hline & ER stress & $\uparrow$ & $\vdash$ & Human, Mouse, Rat & [252-254] \\
\hline & Autophagy & $\uparrow$ & $\vdash$ & Human, Mouse, Rat & [255-258] \\
\hline & Lipid accumulation & $\uparrow$ & $\vdash$ & Human, Mouse, Rat & [259-262] \\
\hline
\end{tabular}

* A calorie restriction (CR) diet supplemented with fish oil. SASP, senescence-associated secretory phenotype; IL-1 $\beta$, Interleukin 1 beta; IL-6R, Interleukin 6 receptor; TNF- $\alpha$, Tumor necrosis factor-alpha; MCP-1, Monocyte chemoattractant protein-1; MIP-1 $\alpha$, Macrophage inflammatory protein-1alpha; MMP, Matrix metallopeptidases; GF, Growth factor; HGF, Hepatocyte Growth Factor; EGFR, Epidermal growth factor receptor; FAS, Apoptosis Antigen 1; IGFBP2, Insulin Like Growth Factor Binding Protein 2; TCGA, The Cancer Genome Atlas.

Author Contributions: Conceptualization, design and writing of the work: D.H.K., E.B., H.J.J., S.G.N., B.P.Y., Y.J.C. and H.Y.C. All authors have read and agreed to the published version of the manuscript.

Funding: This study was supported by the Korean National Research Foundation (NRF) funded by the Korean government (NRF-2018R1A2A3075425 and NRF-2015M3A9B8029074).

Acknowledgments: We thank Aging Tissue Bank (Busan, Korea) for providing research information.

Conflicts of Interest: The authors declare no conflict of interest. 


\section{References}

1. Yu, B.P. Aging and oxidative stress: Modulation by dietary restriction. Free Radic. Biol. Med. 1996, 21, 651-668. [CrossRef]

2. Bektas, A.; Schurman, S.H.; Sen, R.; Ferrucci, L. Aging, inflammation and the environment. Exp. Gerontol. 2018, 105, 10-18. [CrossRef]

3. Chhetri, J.K.; de Souto Barreto, P.; Fougere, B.; Rolland, Y.; Vellas, B.; Cesari, M. Chronic inflammation and sarcopenia: A regenerative cell therapy perspective. Exp. Gerontol. 2018, 103, 115-123. [CrossRef] [PubMed]

4. Franceschi, C.; Garagnani, P.; Vitale, G.; Capri, M.; Salvioli, S. Inflammaging and 'Garb-aging'. Trends Endocrinol. Metab. 2017, 28, 199-212. [CrossRef] [PubMed]

5. Fulop, T.; Larbi, A.; Dupuis, G.; Le Page, A.; Frost, E.H.; Cohen, A.A.; Witkowski, J.M.; Franceschi, C. Immunosenescence and Inflamm-Aging As Two Sides of the Same Coin: Friends or Foes? Front. Immunol. 2017, 8, 1960. [CrossRef] [PubMed]

6. Fougere, B.; Boulanger, E.; Nourhashemi, F.; Guyonnet, S.; Cesari, M. Chronic Inflammation: Accelerator of Biological Aging. J. Gerontol. A Biol. Sci. Med. Sci. 2017, 72, 1218-1225. [CrossRef]

7. Kuilman, T.; Peeper, D.S. Senescence-messaging secretome: SMS-ing cellular stress. Nat. Rev. Cancer 2009, 9, 81-94. [CrossRef]

8. Vasto, S.; Candore, G.; Balistreri, C.R.; Caruso, M.; Colonna-Romano, G.; Grimaldi, M.P.; Listi, F.; Nuzzo, D.; Lio, D.; Caruso, C. Inflammatory networks in ageing, age-related diseases and longevity. Mech. Ageing Dev. 2007, 128, 83-91. [CrossRef]

9. Rea, I.M.; Gibson, D.S.; McGilligan, V.; McNerlan, S.E.; Alexander, H.D.; Ross, O.A. Age and Age-Related Diseases: Role of Inflammation Triggers and Cytokines. Front. Immunol. 2018, 9, 586. [CrossRef]

10. Yu, B.P. Calorie restriction as a potent anti-aging intervention: Modulation of oxidative stress. In Aging Interventions and Therapies; World Scientific Publishing Co.: Singapore, 2005; pp. 193-217.

11. Stepanyan, Z.; Hughes, B.; Cliche, D.O.; Camp, D.; Hekimi, S. Genetic and molecular characterization of CLK-1/mCLK1, a conserved determinant of the rate of aging. Exp. Gerontol. 2006, 41, 940-951. [CrossRef]

12. Childs, B.G.; Gluscevic, M.; Baker, D.J.; Laberge, R.-M.; Marquess, D.; Dananberg, J.; van Deursen, J.M. Senescent cells: An emerging target for diseases of ageing. Nat. Rev. Drug Discov. 2017, 16, 718-735. [CrossRef] [PubMed]

13. Shaw, A.C.; Joshi, S.; Greenwood, H.; Panda, A.; Lord, J.M. Aging of the innate immune system. Curr. Opin. Immunol. 2010, 22, 507-513. [CrossRef] [PubMed]

14. Shaw, A.C.; Goldstein, D.R.; Montgomery, R.R. Age-dependent dysregulation of innate immunity. Nat. Rev. Immunol. 2013, 13, 875-887. [CrossRef] [PubMed]

15. Rawji, K.S.; Mishra, M.K.; Michaels, N.J.; Rivest, S.; Stys, P.K.; Yong, V.W. Immunosenescence of microglia and macrophages: Impact on the ageing central nervous system. Brain 2016, 139, 653-661. [CrossRef]

16. Oishi, Y.; Manabe, I. Macrophages in age-related chronic inflammatory diseases. NPJ Aging Mech. Dis. 2016, 2, 16018. [CrossRef]

17. Chung, H.Y.; Kim, D.H.; Lee, E.K.; Chung, K.W.; Chung, S.; Lee, B.; Seo, A.Y.; Chung, J.H.; Jung, Y.S.; Im, E.; et al. Redefining Chronic Inflammation in Aging and Age-Related Diseases: Proposal of the Senoinflammation Concept. Aging Dis. 2019, 10, 367-382. [CrossRef]

18. Irvine, K.M.; Skoien, R.; Bokil, N.J.; Melino, M.; Thomas, G.P.; Loo, D.; Gabrielli, B.; Hill, M.M.; Sweet, M.J.; Clouston, A.D.; et al. Senescent human hepatocytes express a unique secretory phenotype and promote macrophage migration. World J. Gastroenterol. 2014, 20, 17851-17862. [CrossRef]

19. Wang, C.; Jurk, D.; Maddick, M.; Nelson, G.; Martin-Ruiz, C.; von Zglinicki, T. DNA damage response and cellular senescence in tissues of aging mice. Aging Cell 2009, 8, 311-323. [CrossRef]

20. Castro, R.E.; Ferreira, D.M.; Afonso, M.B.; Borralho, P.M.; Machado, M.V.; Cortez-Pinto, H.; Rodrigues, C.M. $\mathrm{miR}-34 \mathrm{a} / \mathrm{SIRT} 1 / \mathrm{p} 53$ is suppressed by ursodeoxycholic acid in the rat liver and activated by disease severity in human non-alcoholic fatty liver disease. J. Hepatol. 2013, 58, 119-125. [CrossRef]

21. Ogrodnik, M.; Miwa, S.; Tchkonia, T.; Tiniakos, D.; Wilson, C.L.; Lahat, A.; Day, C.P.; Burt, A.; Palmer, A.; Anstee, Q.M.; et al. Cellular senescence drives age-dependent hepatic steatosis. Nat. Commun. 2017, 8, 15691. [CrossRef] 
22. Chung, H.Y.; Lee, E.K.; Choi, Y.J.; Kim, J.M.; Kim, D.H.; Zou, Y.; Kim, C.H.; Lee, J.; Kim, H.S.; Kim, N.D.; et al. Molecular inflammation as an underlying mechanism of the aging process and age-related diseases. J. Dent. Res. 2011, 90, 830-840. [CrossRef]

23. Hoesel, B.; Schmid, J.A. The complexity of NF-kappaB signaling in inflammation and cancer. Mol. Cancer 2013, 12, 86. [CrossRef] [PubMed]

24. Patel, M.; Horgan, P.G.; McMillan, D.C.; Edwards, J. NF-kappaB pathways in the development and progression of colorectal cancer. Transl. Res. 2018, 197, 43-56. [CrossRef] [PubMed]

25. Kriete, A.; Mayo, K.L.; Yalamanchili, N.; Beggs, W.; Bender, P.; Kari, C.; Rodeck, U. Cell autonomous expression of inflammatory genes in biologically aged fibroblasts associated with elevated NF-kappaB activity. Immun. Ageing 2008, 5, 5. [CrossRef] [PubMed]

26. Bektas, A.; Zhang, Y.; Lehmann, E.; Wood, W.H., 3rd; Becker, K.G.; Madara, K.; Ferrucci, L.; Sen, R. Age-associated changes in basal NF-kappaB function in human $\mathrm{CD}^{+} \mathrm{T}$ lymphocytes via dysregulation of PI3 kinase. Aging (Albany NY) 2014, 6, 957-974. [CrossRef]

27. Esparza-Lopez, J.; Alvarado-Munoz, J.F.; Escobar-Arriaga, E.; Ulloa-Aguirre, A.; de Jesus Ibarra-Sanchez, M. Metformin reverses mesenchymal phenotype of primary breast cancer cells through STAT3/NF-kappaB pathways. BMC Cancer 2019, 19, 728. [CrossRef]

28. Liu, L.; Liu, Y.; Liu, X.; Zhang, N.; Mao, G.; Zeng, Q.; Yin, M.; Song, D.; Deng, H. Resibufogenin suppresses transforming growth factor-beta-activated kinase 1-mediated nuclear factor-kappaB activity through protein kinase C-dependent inhibition of glycogen synthase kinase 3. Cancer Sci. 2018, 109, 3611-3622. [CrossRef]

29. Chung, H.Y.; Cesari, M.; Anton, S.; Marzetti, E.; Giovannini, S.; Seo, A.Y.; Carter, C.; Yu, B.P.; Leeuwenburgh, C. Molecular inflammation: Underpinnings of aging and age-related diseases. Ageing Res. Rev. 2009, 8, 18-30. [CrossRef]

30. Tabas, I.; Glass, C.K. Anti-inflammatory therapy in chronic disease: Challenges and opportunities. Science 2013, 339, 166-172. [CrossRef]

31. Bruunsgaard, H.; Pedersen, B.K. Age-related inflammatory cytokines and disease. Immunol. Allergy Clin. N. Am. 2003, 23, 15-39. [CrossRef]

32. Soysal, P.; Stubbs, B.; Lucato, P.; Luchini, C.; Solmi, M.; Peluso, R.; Sergi, G.; Isik, A.T.; Manzato, E.; Maggi, S.; et al. Inflammation and frailty in the elderly: A systematic review and meta-analysis. Ageing Res. Rev. 2016, 31, 1-8. [CrossRef] [PubMed]

33. Arai, Y.; Martin-Ruiz, C.M.; Takayama, M.; Abe, Y.; Takebayashi, T.; Koyasu, S.; Suematsu, M.; Hirose, N.; von Zglinicki, T. Inflammation, But Not Telomere Length, Predicts Successful Ageing at Extreme Old Age: A Longitudinal Study of Semi-supercentenarians. EBioMedicine 2015, 2, 1549-1558. [CrossRef] [PubMed]

34. Michaud, M.; Balardy, L.; Moulis, G.; Gaudin, C.; Peyrot, C.; Vellas, B.; Cesari, M.; Nourhashemi, F. Proinflammatory cytokines, aging, and age-related diseases. J. Am. Med. Dir. Assoc. 2013, 14, 877-882. [CrossRef] [PubMed]

35. Fontana, L.; Partridge, L.; Longo, V.D. Extending healthy life span-From yeast to humans. Science 2010, 328, 321-326. [CrossRef] [PubMed]

36. Mitchell, S.J.; Madrigal-Matute, J.; Scheibye-Knudsen, M.; Fang, E.; Aon, M.; Gonzalez-Reyes, J.A.; Cortassa, S.; Kaushik, S.; Gonzalez-Freire, M.; Patel, B.; et al. Effects of Sex, Strain, and Energy Intake on Hallmarks of Aging in Mice. Cell Metab. 2016, 23, 1093-1112. [CrossRef] [PubMed]

37. Brandhorst, S.; Longo, V.D. Fasting and Caloric Restriction in Cancer Prevention and Treatment. Recent Results Cancer Res. 2016, 207, 241-266. [CrossRef]

38. Chen, J.; Astle, C.M.; Harrison, D.E. Delayed immune aging in diet-restricted B6CBAT6 F1 mice is associated with preservation of naive T cells. J. Gerontol. A Biol. Sci. Med. Sci. 1998, 53, B330-B337. [CrossRef]

39. Walford, R.L.; Liu, R.K.; Gerbase-Delima, M.; Mathies, M.; Smith, G.S. Longterm dietary restriction and immune function in mice: Response to sheep red blood cells and to mitogenic agents. Mech. Ageing Dev. 1973, 2, 447-454. [CrossRef]

40. Weindruch, R.; Devens, B.H.; Raff, H.V.; Walford, R.L. Influence of dietary restriction and aging on natural killer cell activity in mice. J. Immunol. 1983, 130, 993-996.

41. Weindruch, R.; Gottesman, S.R.; Walford, R.L. Modification of age-related immune decline in mice dietarily restricted from or after midadulthood. Proc. Natl. Acad. Sci. USA 1982, 79, 898-902. [CrossRef]

42. Weindruch, R.; Walford, R.L. Dietary restriction in mice beginning at 1 year of age: Effect on life-span and spontaneous cancer incidence. Science 1982, 215, 1415-1418. [CrossRef] [PubMed] 
43. Spaulding, C.C.; Walford, R.L.; Effros, R.B. Calorie restriction inhibits the age-related dysregulation of the cytokines TNF-alpha and IL-6 in C3B10RF1 mice. Mech. Ageing Dev. 1997, 93, 87-94. [CrossRef]

44. Fernandes, G.; Friend, P.; Yunis, E.J.; Good, R.A. Influence of dietary restriction on immunologic function and renal disease in (NZB x NZW) F1 mice. Proc. Natl. Acad. Sci. USA 1978, 75, 1500-1504. [CrossRef]

45. Friend, P.S.; Fernandes, G.; Good, R.A.; Michael, A.F.; Yunis, E.J. Dietary restrictions early and late: Effects on the nephropathy of the NZB X NZW mouse. Lab. Investig. 1978, 38, 629-632.

46. McCay, C.M.; Crowell, M.F.; Maynard, L.A. The effect of retarded growth upon the length of life span and upon the ultimate body size. 1935. Nutrition 1989, 5, 155-171, discussion 172.

47. Bordone, L.; Guarente, L. Calorie restriction, SIRT1 and metabolism: Understanding longevity. Nat. Rev. Mol. Cell Biol. 2005, 6, 298-305. [CrossRef]

48. Yu, B.P.; Chung, H.Y. Stress resistance by caloric restriction for longevity. Ann. N. Y. Acad. Sci. 2001, 928, 39-47. [CrossRef]

49. Longo, V.D.; Finch, C.E. Evolutionary medicine: From dwarf model systems to healthy centenarians? Science 2003, 299, 1342-1346. [CrossRef]

50. Demetrius, L. Of mice and men. When it comes to studying ageing and the means to slow it down, mice are not just small humans. EMBO Rep. 2005, 6, S39-S44. [CrossRef]

51. Mattson, M.P.; Duan, W.; Lee, J.; Guo, Z. Suppression of brain aging and neurodegenerative disorders by dietary restriction and environmental enrichment: Molecular mechanisms. Mech. Ageing Dev. 2001, 122, 757-778. [CrossRef]

52. Cohen, D.E.; Supinski, A.M.; Bonkowski, M.S.; Donmez, G.; Guarente, L.P. Neuronal SIRT1 regulates endocrine and behavioral responses to calorie restriction. Genes Dev. 2009, 23, 2812-2817. [CrossRef] [PubMed]

53. Grivennikov, S.I.; Karin, M. Dangerous liaisons: STAT3 and NF-kappaB collaboration and crosstalk in cancer. Cytokine Growth Factor Rev. 2010, 21, 11-19. [CrossRef] [PubMed]

54. Weichhart, T. mTOR as Regulator of Lifespan, Aging, and Cellular Senescence: A Mini-Review. Gerontology 2018, 64, 127-134. [CrossRef] [PubMed]

55. Jung, K.J.; Lee, E.K.; Kim, J.Y.; Zou, Y.; Sung, B.; Heo, H.S.; Kim, M.K.; Lee, J.; Kim, N.D.; Yu, B.P.; et al. Effect of short term calorie restriction on pro-inflammatory NF-kB and AP-1 in aged rat kidney. Inflamm. Res. 2009, 58, 143-150. [CrossRef] [PubMed]

56. Allen, B.D.; Liao, C.Y.; Shu, J.; Muglia, L.J.; Majzoub, J.A.; Diaz, V.; Nelson, J.F. Hyperadrenocorticism of calorie restriction contributes to its anti-inflammatory action in mice. Aging Cell 2019, 18, e12944. [CrossRef] [PubMed]

57. Jin Jung, K.; Hyun Kim, D.; Kyeong Lee, E.; Woo Song, C.; Pal Yu, B.; Young Chung, H. Oxidative stress induces inactivation of protein phosphatase 2A, promoting proinflammatory NF-kappaB in aged rat kidney. Free Radic. Biol. Med. 2013, 61, 206-217. [CrossRef]

58. Meydani, S.N.; Das, S.K.; Pieper, C.F.; Lewis, M.R.; Klein, S.; Dixit, V.D.; Gupta, A.K.; Villareal, D.T.; Bhapkar, M.; Huang, M.; et al. Long-term moderate calorie restriction inhibits inflammation without impairing cell-mediated immunity: A randomized controlled trial in non-obese humans. Aging (Albany NY) 2016, 8, 1416-1431. [CrossRef]

59. Contreras, N.A.; Fontana, L.; Tosti, V.; Nikolich-Zugich, J. Calorie restriction induces reversible lymphopenia and lymphoid organ atrophy due to cell redistribution. Geroscience 2018, 40, 279-291. [CrossRef]

60. Kurki, E.; Shi, J.; Martonen, E.; Finckenberg, P.; Mervaala, E. Distinct effects of calorie restriction on adipose tissue cytokine and angiogenesis profiles in obese and lean mice. Nutr. Metab. (Lon.) 2012, 9, 64. [CrossRef]

61. Park, C.Y.; Park, S.; Kim, M.S.; Kim, H.K.; Han, S.N. Effects of mild calorie restriction on lipid metabolism and inflammation in liver and adipose tissue. Biochem. Biophys. Res. Commun. 2017, 490, 636-642. [CrossRef]

62. Johansson, H.E.; Edholm, D.; Kullberg, J.; Rosqvist, F.; Rudling, M.; Straniero, S.; Karlsson, F.A.; Ahlstrom, H.; Sundbom, M.; Riserus, U. Energy restriction in obese women suggest linear reduction of hepatic fat content and time-dependent metabolic improvements. Nutr. Diabetes 2019, 9, 34. [CrossRef] [PubMed]

63. Masternak, M.M.; Bartke, A. PPARs in Calorie Restricted and Genetically Long-Lived Mice. PPAR Res. 2007, 2007, 28436. [CrossRef] [PubMed]

64. Stankovic, M.; Mladenovic, D.; Ninkovic, M.; Vucevic, D.; Tomasevic, T.; Radosavljevic, T. Effects of caloric restriction on oxidative stress parameters. Gen. Physiol. Biophys. 2013, 32, 277-283. [CrossRef] [PubMed] 
65. Redman, L.M.; Smith, S.R.; Burton, J.H.; Martin, C.K.; Il'yasova, D.; Ravussin, E. Metabolic Slowing and Reduced Oxidative Damage with Sustained Caloric Restriction Support the Rate of Living and Oxidative Damage Theories of Aging. Cell Metab. 2018, 27, 805-815.e804. [CrossRef]

66. Shinmura, K. Effects of caloric restriction on cardiac oxidative stress and mitochondrial bioenergetics: Potential role of cardiac sirtuins. Oxid. Med. Cell. Longev. 2013, 2013, 528935. [CrossRef]

67. Sung, B.; Park, S.; Yu, B.P.; Chung, H.Y. Modulation of PPAR in aging, inflammation, and calorie restriction. J. Gerontol. A Biol. Sci. Med. Sci. 2004, 59, 997-1006. [CrossRef]

68. Nunn, A.V.; Bell, J.; Barter, P. The integration of lipid-sensing and anti-inflammatory effects: How the PPARs play a role in metabolic balance. Nucl. Recept. 2007, 5, 1. [CrossRef]

69. Youssef, J.; Badr, M. Role of Peroxisome Proliferator-Activated Receptors in Inflammation Control. J. Biomed. Biotechnol. 2004, 2004, 156-166. [CrossRef]

70. Canto, C.; Auwerx, J. Caloric restriction, SIRT1 and longevity. Trends Endocrinol. Metab. 2009, $20,325-331$. [CrossRef]

71. Tang, B.L. Sirt1 and the Mitochondria. Mol. Cells 2016, 39, 87-95. [CrossRef]

72. Frescas, D.; Valenti, L.; Accili, D. Nuclear trapping of the forkhead transcription factor FoxO1 via Sirt-dependent deacetylation promotes expression of glucogenetic genes. J. Biol. Chem. 2005, 280, 20589-20595. [CrossRef] [PubMed]

73. Min, S.W.; Sohn, P.D.; Cho, S.H.; Swanson, R.A.; Gan, L. Sirtuins in neurodegenerative diseases: An update on potential mechanisms. Front. Aging Neurosci. 2013, 5, 53. [CrossRef] [PubMed]

74. Park, D.; Kim, B.C.; Kim, C.H.; Choi, Y.J.; Jeong, H.O.; Kim, M.E.; Lee, J.S.; Park, M.H.; Chung, K.W.; Kim, D.H.; et al. RNA-Seq analysis reveals new evidence for inflammation-related changes in aged kidney. Oncotarget 2016, 7, 30037-30048. [CrossRef] [PubMed]

75. Kim, B.C.; Jeong, H.O.; Park, D.; Kim, C.H.; Lee, E.K.; Kim, D.H.; Im, E.; Kim, N.D.; Lee, S.; Yu, B.P.; et al. Profiling age-related epigenetic markers of stomach adenocarcinoma in young and old subjects. Cancer Inform. 2015, 14, 47-54. [CrossRef]

76. Castellani, G.C.; Menichetti, G.; Garagnani, P.; Giulia Bacalini, M.; Pirazzini, C.; Franceschi, C.; Collino, S.; Sala, C.; Remondini, D.; Giampieri, E.; et al. Systems medicine of inflammaging. Brief. Bioinform. 2016, 17, 527-540. [CrossRef]

77. Rusli, F.; Lute, C.; Boekschoten, M.V.; van Dijk, M.; van Norren, K.; Menke, A.L.; Muller, M.; Steegenga, W.T. Intermittent calorie restriction largely counteracts the adverse health effects of a moderate-fat diet in aging C57BL/6J mice. Mol. Nutr. Food Res. 2017, 61, 1600677. [CrossRef]

78. Derous, D.; Mitchell, S.E.; Green, C.L.; Wang, Y.; Han, J.D.J.; Chen, L.; Promislow, D.E.L.; Lusseau, D.; Douglas, A.; Speakman, J.R. The Effects of Graded Levels of Calorie Restriction: X. Transcriptomic Responses of Epididymal Adipose Tissue. J. Gerontol. Ser. A Biol. Sci. Med Sci. 2018, 73, 279-288. [CrossRef]

79. Green, C.L.; Mitchell, S.E.; Derous, D.; Wang, Y.; Chen, L.; Han, J.J.; Promislow, D.E.L.; Lusseau, D.; Douglas, A.; Speakman, J.R. The effects of graded levels of calorie restriction: IX. Global metabolomic screen reveals modulation of carnitines, sphingolipids and bile acids in the liver of C57BL/6 mice. Aging Cell 2017, 16, 529-540. [CrossRef]

80. Derous, D.; Mitchell, S.E.; Green, C.L.; Wang, Y.; Han, J.D.; Chen, L.; Promislow, D.E.; Lusseau, D.; Speakman, J.R.; Douglas, A. The effects of graded levels of calorie restriction: VII. Topological rearrangement of hypothalamic aging networks. Aging 2016, 8, 917-932. [CrossRef]

81. Dao, M.C.; Sokolovska, N.; Brazeilles, R.; Affeldt, S.; Pelloux, V.; Prifti, E.; Chilloux, J.; Verger, E.O.; Kayser, B.D.; Aron-Wisnewsky, J.; et al. A Data Integration Multi-Omics Approach to Study Calorie Restriction-Induced Changes in Insulin Sensitivity. Front. Physiol. 2018, 9, 1958. [CrossRef]

82. Park, D.; Lee, E.K.; Jang, E.J.; Jeong, H.O.; Kim, B.C.; Ha, Y.M.; Hong, S.E.; Yu, B.P.; Chung, H.Y. Identification of the dichotomous role of age-related LCK in calorie restriction revealed by integrative analysis of cDNA microarray and interactome. Age 2013, 35, 1045-1060. [CrossRef] [PubMed]

83. Hong, S.E.; Heo, H.S.; Kim, D.H.; Kim, M.S.; Kim, C.H.; Lee, J.; Yoo, M.A.; Yu, B.P.; Leeuwenburgh, C.; Chung, H.Y. Revealing system-level correlations between aging and calorie restriction using a mouse transcriptome. Age 2010, 32, 15-30. [CrossRef] [PubMed]

84. Kim, C.H.; Lee, E.K.; Choi, Y.J.; An, H.J.; Jeong, H.O.; Park, D.; Kim, B.C.; Yu, B.P.; Bhak, J.; Chung, H.Y. Short-term calorie restriction ameliorates genomewide, age-related alterations in DNA methylation. Aging Cell 2016, 15, 1074-1081. [CrossRef] [PubMed] 
85. Derous, D.; Mitchell, S.E.; Wang, L.; Green, C.L.; Wang, Y.; Chen, L.; Han, J.J.; Promislow, D.E.L.; Lusseau, D.; Douglas, A.; et al. The effects of graded levels of calorie restriction: XI. Evaluation of the main hypotheses underpinning the life extension effects of CR using the hepatic transcriptome. Aging 2017, 9, 1770-1824. [CrossRef] [PubMed]

86. Wanders, D.; Ghosh, S.; Stone, K.P.; Van, N.T.; Gettys, T.W. Transcriptional impact of dietary methionine restriction on systemic inflammation: Relevance to biomarkers of metabolic disease during aging. BioFactors 2014, 40, 13-26. [CrossRef]

87. Valle, A.; Sastre-Serra, J.; Roca, P.; Oliver, J. Modulation of white adipose tissue proteome by aging and calorie restriction. Aging Cell 2010, 9, 882-894. [CrossRef]

88. Jove, M.; Naudi, A.; Ramirez-Nunez, O.; Portero-Otin, M.; Selman, C.; Withers, D.J.; Pamplona, R. Caloric restriction reveals a metabolomic and lipidomic signature in liver of male mice. Aging Cell 2014, 13, 828-837. [CrossRef]

89. Simpson, S.J.; Le Couteur, D.G.; Raubenheimer, D.; Solon-Biet, S.M.; Cooney, G.J.; Cogger, V.C.; Fontana, L. Dietary protein, aging and nutritional geometry. Ageing Res. Rev. 2017, 39, 78-86. [CrossRef]

90. Mair, W.; Piper, M.D.; Partridge, L. Calories do not explain extension of life span by dietary restriction in Drosophila. PLoS Biol. 2005, 3, e223. [CrossRef]

91. Solon-Biet, S.M.; McMahon, A.C.; Ballard, J.W.; Ruohonen, K.; Wu, L.E.; Cogger, V.C.; Warren, A.; Huang, X.; Pichaud, N.; Melvin, R.G.; et al. The ratio of macronutrients, not caloric intake, dictates cardiometabolic health, aging, and longevity in ad libitum-fed mice. Cell Metab. 2014, 19, 418-430. [CrossRef]

92. Grandison, R.C.; Piper, M.D.; Partridge, L. Amino-acid imbalance explains extension of lifespan by dietary restriction in Drosophila. Nature 2009, 462, 1061-1064. [CrossRef] [PubMed]

93. Fontana, L.; Cummings, N.E.; Arriola Apelo, S.I.; Neuman, J.C.; Kasza, I.; Schmidt, B.A.; Cava, E.; Spelta, F.; Tosti, V.; Syed, F.A.; et al. Decreased Consumption of Branched-Chain Amino Acids Improves Metabolic Health. Cell Rep. 2016, 16, 520-530. [CrossRef] [PubMed]

94. Longo, V.D.; Mattson, M.P. Fasting: Molecular mechanisms and clinical applications. Cell. Metab. 2014, 19, 181-192. [CrossRef] [PubMed]

95. Gonidakis, S.; Finkel, S.E.; Longo, V.D. Genome-wide screen identifies Escherichia coli TCA-cycle-related mutants with extended chronological lifespan dependent on acetate metabolism and the hypoxia-inducible transcription factor ArcA. Aging Cell 2010, 9, 868-881. [CrossRef]

96. Wei, M.; Fabrizio, P.; Hu, J.; Ge, H.; Cheng, C.; Li, L.; Longo, V.D. Life span extension by calorie restriction depends on Rim15 and transcription factors downstream of Ras/PKA, Tor, and Sch9. PLoS. Genet. 2008, 4, e13. [CrossRef]

97. Kaeberlein, T.L.; Smith, E.D.; Tsuchiya, M.; Welton, K.L.; Thomas, J.H.; Fields, S.; Kennedy, B.K.; Kaeberlein, M. Lifespan extension in Caenorhabditis elegans by complete removal of food. Aging Cell 2006, 5, 487-494. [CrossRef]

98. Goodrick, C.L.; Ingram, D.K.; Reynolds, M.A.; Freeman, J.R.; Cider, N. Effects of intermittent feeding upon body weight and lifespan in inbred mice: Interaction of genotype and age. Mech. Ageing Dev. 1990, 55, 69-87. [CrossRef]

99. Brandhorst, S.; Choi, I.Y.; Wei, M.; Cheng, C.W.; Sedrakyan, S.; Navarrete, G.; Dubeau, L.; Yap, L.P.; Park, R.; Vinciguerra, M.; et al. A Periodic Diet that Mimics Fasting Promotes Multi-System Regeneration, Enhanced Cognitive Performance, and Healthspan. Cell Metab. 2015, 22, 86-99. [CrossRef]

100. Singh, S.; Singh, A.K.; Garg, G.; Rizvi, S.I. Fisetin as a caloric restriction mimetic protects rat brain against aging induced oxidative stress, apoptosis and neurodegeneration. Life Sci. 2018, 193, 171-179. [CrossRef]

101. Choi, K.M.; Lee, H.L.; Kwon, Y.Y.; Kang, M.S.; Lee, S.K.; Lee, C.K. Enhancement of mitochondrial function correlates with the extension of lifespan by caloric restriction and caloric restriction mimetics in yeast. Biochem. Biophys. Res. Commun. 2013, 441, 236-242. [CrossRef]

102. Shintani, H.; Shintani, T.; Ashida, H.; Sato, M. Calorie Restriction Mimetics: Upstream-Type Compounds for Modulating Glucose Metabolism. Nutrients 2018, 10, 1821. [CrossRef] [PubMed]

103. Madeo, F.; Carmona-Gutierrez, D.; Hofer, S.J.; Kroemer, G. Caloric Restriction Mimetics against Age-Associated Disease: Targets, Mechanisms, and Therapeutic Potential. Cell Metab. 2019, 29, 592-610. [CrossRef] [PubMed] 
104. Howitz, K.T.; Bitterman, K.J.; Cohen, H.Y.; Lamming, D.W.; Lavu, S.; Wood, J.G.; Zipkin, R.E.; Chung, P.; Kisielewski, A.; Zhang, L.L.; et al. Small molecule activators of sirtuins extend Saccharomyces cerevisiae lifespan. Nature 2003, 425, 191-196. [CrossRef] [PubMed]

105. Baur, J.A.; Pearson, K.J.; Price, N.L.; Jamieson, H.A.; Lerin, C.; Kalra, A.; Prabhu, V.V.; Allard, J.S.; Lopez-Lluch, G.; Lewis, K.; et al. Resveratrol improves health and survival of mice on a high-calorie diet. Nature 2006, 444, 337-342. [CrossRef]

106. Collins, J.J.; Evason, K.; Kornfeld, K. Pharmacology of delayed aging and extended lifespan of Caenorhabditis elegans. Exp. Gerontol. 2006, 41, 1032-1039. [CrossRef]

107. Bass, T.M.; Weinkove, D.; Houthoofd, K.; Gems, D.; Partridge, L. Effects of resveratrol on lifespan in Drosophila melanogaster and Caenorhabditis elegans. Mech. Ageing Dev. 2007, 128, 546-552. [CrossRef]

108. Rascon, B.; Hubbard, B.P.; Sinclair, D.A.; Amdam, G.V. The lifespan extension effects of resveratrol are conserved in the honey bee and may be driven by a mechanism related to caloric restriction. Aging 2012, 4, 499-508. [CrossRef]

109. Wang, C.; Wheeler, C.T.; Alberico, T.; Sun, X.; Seeberger, J.; Laslo, M.; Spangler, E.; Kern, B.; de Cabo, R.; Zou, $\mathrm{S}$. The effect of resveratrol on lifespan depends on both gender and dietary nutrient composition in Drosophila melanogaster. Age 2013, 35, 69-81. [CrossRef]

110. Baur, J.A.; Sinclair, D.A. Therapeutic potential of resveratrol: The in vivo evidence. Nat. Rev. Drug Discov. 2006, 5, 493-506. [CrossRef]

111. Tsai, Y.F.; Chen, C.Y.; Chang, W.Y.; Syu, Y.T.; Hwang, T.L. Resveratrol suppresses neutrophil activation via inhibition of Src family kinases to attenuate lung injury. Free Radic. Biol. Med. 2019, 145, 67-77. [CrossRef]

112. Wang, L.L.; Shi, D.L.; Gu, H.Y.; Zheng, M.Z.; Hu, J.; Song, X.H.; Shen, Y.L.; Chen, Y.Y. Resveratrol attenuates inflammatory hyperalgesia by inhibiting glial activation in mice spinal cords. Mol. Med. Rep. 2016, 13, 4051-4057. [CrossRef] [PubMed]

113. Aghamiri, S.; Jafarpour, A.; Zandsalimi, F.; Aghemiri, M.; Shoja, M. Effect of resveratrol on the radiosensitivity of 5-FU in human breast cancer MCF-7 cells. J. Cell. Biochem. 2019, 120, 15671-15677. [CrossRef] [PubMed]

114. Chassot, L.N.; Scolaro, B.; Roschel, G.G.; Cogliati, B.; Cavalcanti, M.F.; Abdalla, D.S.P.; Castro, I.A. Comparison between red wine and isolated trans-resveratrol on the prevention and regression of atherosclerosis in LDLr ((-/-)) mice. J. Nutr. Biochem. 2018, 61, 48-55. [CrossRef] [PubMed]

115. Figueira, L.; Gonzalez, J.C. Effect of resveratrol on seric vascular endothelial growth factor concentrations during atherosclerosis. Clin. Investig. Arterioscler. 2018, 30, 209-216. [CrossRef]

116. Lomholt, S.; Mellemkjaer, A.; Iversen, M.B.; Pedersen, S.B.; Kragstrup, T.W. Resveratrol displays anti-inflammatory properties in an ex vivo model of immune mediated inflammatory arthritis. BMC Rheumatol. 2018, 2, 27. [CrossRef]

117. Oz, B.; Yildirim, A.; Yolbas, S.; Celik, Z.B.; Etem, E.O.; Deniz, G.; Akin, M.; Akar, Z.A.; Karatas, A.; Koca, S.S. Resveratrol inhibits Src tyrosine kinase, STAT3, and Wnt signaling pathway in collagen induced arthritis model. BioFactors 2019, 45, 69-74. [CrossRef]

118. Wang, H.M.; Li, G.X.; Zheng, H.S.; Wu, X.Z. Protective effect of resveratrol on lens epithelial cell apoptosis in diabetic cataract rat. Asian Pac. J. Trop. Med. 2015, 8, 153-156. [CrossRef]

119. Zheng, Y.; Liu, Y.; Ge, J.; Wang, X.; Liu, L.; Bu, Z.; Liu, P. Resveratrol protects human lens epithelial cells against $\mathrm{H} 2 \mathrm{O} 2$-induced oxidative stress by increasing catalase, SOD-1, and HO-1 expression. Mol. Vis. 2010, $16,1467-1474$.

120. Higashi, Y.; Higashi, K.; Mori, A.; Sakamoto, K.; Ishii, K.; Nakahara, T. Anti-cataract Effect of Resveratrol in High-Glucose-Treated Streptozotocin-Induced Diabetic Rats. Biol. Pharm. Bull. 2018, 41, 1586-1592. [CrossRef]

121. Huo, X.; Zhang, T.; Meng, Q.; Li, C.; You, B. Resveratrol Effects on a Diabetic Rat Model with Coronary Heart Disease. Med Sci. Monit. Int. Med J. Exp. Clin. Res. 2019, 25, 540-546. [CrossRef]

122. Sarkar, O.; Li, Y.; Anand-Srivastava, M.B. Resveratrol prevents the development of high blood pressure in spontaneously hypertensive rats through the inhibition of enhanced expression of Gialpha proteins (1). Can. J. Physiol. Pharmacol. 2019, 97, 872-879. [CrossRef] [PubMed]

123. Yousefian, M.; Shakour, N.; Hosseinzadeh, H.; Hayes, A.W.; Hadizadeh, F.; Karimi, G. The natural phenolic compounds as modulators of NADPH oxidases in hypertension. Phytomed. Int. J. Phytother. Phytopharm. 2019, 55, 200-213. [CrossRef] [PubMed] 
124. Szkudelski, T.; Szkudelska, K. Resveratrol and diabetes: From animal to human studies. Biochim. Biophys. Acta 2015, 1852, 1145-1154. [CrossRef] [PubMed]

125. Ozturk, E.; Arslan, A.K.K.; Yerer, M.B.; Bishayee, A. Resveratrol and diabetes: A critical review of clinical studies. Biomed. Pharmacother. Biomed. Pharmacother. 2017, 95, 230-234. [CrossRef] [PubMed]

126. Cheang, W.S.; Wong, W.T.; Wang, L.; Cheng, C.K.; Lau, C.W.; Ma, R.C.W.; Xu, A.; Wang, N.; Huang, Y.; Tian, X.Y. Resveratrol ameliorates endothelial dysfunction in diabetic and obese mice through sirtuin 1 and peroxisome proliferator-activated receptor delta. Pharmacol. Res. 2019, 139, 384-394. [CrossRef] [PubMed]

127. Javid, A.Z.; Hormoznejad, R.; Yousefimanesh, H.A.; Haghighi-Zadeh, M.H.; Zakerkish, M. Impact of resveratrol supplementation on inflammatory, antioxidant, and periodontal markers in type 2 diabetic patients with chronic periodontitis. Diabetes Metab. Syndr. 2019, 13, 2769-2774. [CrossRef] [PubMed]

128. Wang, X.; Chen, L.; Peng, W. Protective effects of resveratrol on osteoporosis via activation of the SIRT1-NF-kappaB signaling pathway in rats. Exp. Ther. Med. 2017, 14, 5032-5038. [CrossRef]

129. Feng, Y.L.; Jiang, X.T.; Ma, F.F.; Han, J.; Tang, X.L. Resveratrol prevents osteoporosis by upregulating FoxO1 transcriptional activity. Int. J. Mol. Med. 2018, 41, 202-212. [CrossRef]

130. Li, J.; Xin, Z.; Cai, M. The role of resveratrol in bone marrow-derived mesenchymal stem cells from patients with osteoporosis. J. Cell. Biochem. 2019, 120, 16634-16642. [CrossRef]

131. Kim, D.; Nguyen, M.D.; Dobbin, M.M.; Fischer, A.; Sananbenesi, F.; Rodgers, J.T.; Delalle, I.; Baur, J.A.; Sui, G.; Armour, S.M.; et al. SIRT1 deacetylase protects against neurodegeneration in models for Alzheimer's disease and amyotrophic lateral sclerosis. EMBO J. 2007, 26, 3169-3179. [CrossRef]

132. Alkhouli, M.F.; Hung, J.; Squire, M.; Anderson, M.; Castro, M.; Babu, J.R.; Al-Nakkash, L.; Broderick, T.L.; Plochocki, J.H. Exercise and resveratrol increase fracture resistance in the $3 x \mathrm{Tg}-\mathrm{AD}$ mouse model of Alzheimer's disease. BMC Complement. Altern. Med. 2019, 19, 39. [CrossRef] [PubMed]

133. Cosin-Tomas, M.; Senserrich, J.; Arumi-Planas, M.; Alquezar, C.; Pallas, M.; Martin-Requero, A.; Sunol, C.; Kaliman, P.; Sanfeliu, C. Role of Resveratrol and Selenium on Oxidative Stress and Expression of Antioxidant and Anti-Aging Genes in Immortalized Lymphocytes from Alzheimer's Disease Patients. Nutrients 2019, 11, 1764. [CrossRef] [PubMed]

134. Timmers, S.; Konings, E.; Bilet, L.; Houtkooper, R.H.; van de Weijer, T.; Goossens, G.H.; Hoeks, J.; van der Krieken, S.; Ryu, D.; Kersten, S.; et al. Calorie restriction-like effects of 30 days of resveratrol supplementation on energy metabolism and metabolic profile in obese humans. Cell Metab. 2011, 14, 612-622. [CrossRef]

135. Witte, A.V.; Kerti, L.; Margulies, D.S.; Floel, A. Effects of resveratrol on memory performance, hippocampal functional connectivity, and glucose metabolism in healthy older adults. J. Neurosci. Off. J. Soc. Neurosci. 2014, 34, 7862-7870. [CrossRef]

136. Liu, S.; Zheng, Z.; Ji, S.; Liu, T.; Hou, Y.; Li, S.; Li, G. Resveratrol reduces senescence-associated secretory phenotype by SIRT1/NF-kappaB pathway in gut of the annual fish Nothobranchius guentheri. Fish Shellfish Immunol. 2018, 80, 473-479. [CrossRef]

137. Chang, Y.C.; Liu, H.W.; Chen, Y.T.; Chen, Y.A.; Chen, Y.J.; Chang, S.J. Resveratrol protects muscle cells against palmitate-induced cellular senescence and insulin resistance through ameliorating autophagic flux. J. Food Drug Anal. 2018, 26, 1066-1074. [CrossRef]

138. Kirpichnikov, D.; McFarlane, S.I.; Sowers, J.R. Metformin: An update. Ann. Intern. Med. 2002, 137, $25-33$. [CrossRef]

139. Cabreiro, F.; Au, C.; Leung, K.Y.; Vergara-Irigaray, N.; Cocheme, H.M.; Noori, T.; Weinkove, D.; Schuster, E.; Greene, N.D.; Gems, D. Metformin retards aging in C. elegans by altering microbial folate and methionine metabolism. Cell 2013, 153, 228-239. [CrossRef]

140. De Haes, W.; Frooninckx, L.; Van Assche, R.; Smolders, A.; Depuydt, G.; Billen, J.; Braeckman, B.P.; Schoofs, L.; Temmerman, L. Metformin promotes lifespan through mitohormesis via the peroxiredoxin PRDX-2. Proc. Natl. Acad. Sci. USA 2014, 111, E2501-E2509. [CrossRef]

141. Wu, L.; Zhou, B.; Oshiro-Rapley, N.; Li, M.; Paulo, J.A.; Webster, C.M.; Mou, F.; Kacergis, M.C.; Talkowski, M.E.; Carr, C.E.; et al. An Ancient, Unified Mechanism for Metformin Growth Inhibition in C. elegans and Cancer. Cell 2016, 167, 1705-1718.e1713. [CrossRef]

142. Slack, C.; Foley, A.; Partridge, L. Activation of AMPK by the putative dietary restriction mimetic metformin is insufficient to extend lifespan in Drosophila. PLoS ONE 2012, 7, e47699. [CrossRef] [PubMed] 
143. Onken, B.; Driscoll, M. Metformin induces a dietary restriction-like state and the oxidative stress response to extend C. elegans Healthspan via AMPK, LKB1, and SKN-1. PLoS ONE 2010, 5, e8758. [CrossRef] [PubMed]

144. Martin-Montalvo, A.; Mercken, E.M.; Mitchell, S.J.; Palacios, H.H.; Mote, P.L.; Scheibye-Knudsen, M.; Gomes, A.P.; Ward, T.M.; Minor, R.K.; Blouin, M.J.; et al. Metformin improves healthspan and lifespan in mice. Nat. Commun. 2013, 4, 2192. [CrossRef] [PubMed]

145. Barzilai, N.; Crandall, J.P.; Kritchevsky, S.B.; Espeland, M.A. Metformin as a Tool to Target Aging. Cell Metab. 2016, 23, 1060-1065. [CrossRef] [PubMed]

146. Chen, J.; Ou, Y.; Li, Y.; Hu, S.; Shao, L.W.; Liu, Y. Metformin extends C. elegans lifespan through lysosomal pathway. Elife 2017, 6, e31268. [CrossRef] [PubMed]

147. Collier, C.A.; Bruce, C.R.; Smith, A.C.; Lopaschuk, G.; Dyck, D.J. Metformin counters the insulin-induced suppression of fatty acid oxidation and stimulation of triacylglycerol storage in rodent skeletal muscle. Am. J. Physiol. Endocrinol. Metab. 2006, 291, E182-E189. [CrossRef] [PubMed]

148. Kim, Y.D.; Park, K.G.; Lee, Y.S.; Park, Y.Y.; Kim, D.K.; Nedumaran, B.; Jang, W.G.; Cho, W.J.; Ha, J.; Lee, I.K.; et al. Metformin inhibits hepatic gluconeogenesis through AMP-activated protein kinase-dependent regulation of the orphan nuclear receptor SHP. Diabetes 2008, 57, 306-314. [CrossRef]

149. Wu, K.; Tian, R.; Huang, J.; Yang, Y.; Dai, J.; Jiang, R.; Zhang, L. Metformin alleviated endotoxemia-induced acute lung injury via restoring AMPK-dependent suppression of mTOR. Chem. Biol. Interact. 2018, 291, 1-6. [CrossRef]

150. Algire, C.; Moiseeva, O.; Deschenes-Simard, X.; Amrein, L.; Petruccelli, L.; Birman, E.; Viollet, B.; Ferbeyre, G.; Pollak, M.N. Metformin reduces endogenous reactive oxygen species and associated DNA damage. Cancer Prev. Res. 2012, 5, 536-543. [CrossRef]

151. Marinello, P.C.; da Silva, T.N.; Panis, C.; Neves, A.F.; Machado, K.L.; Borges, F.H.; Guarnier, F.A.; Bernardes, S.S.; de-Freitas-Junior, J.C.; Morgado-Diaz, J.A.; et al. Mechanism of metformin action in MCF-7 and MDA-MB-231 human breast cancer cells involves oxidative stress generation, DNA damage, and transforming growth factor beta1 induction. Tumour Biol. J. Int. Soc. Oncodev. Biol. Med. 2016, 37, 5337-5346. [CrossRef]

152. Sarfstein, R.; Friedman, Y.; Attias-Geva, Z.; Fishman, A.; Bruchim, I.; Werner, H. Metformin downregulates the insulin/IGF-I signaling pathway and inhibits different uterine serous carcinoma (USC) cells proliferation and migration in p53-dependent or -independent manners. PLoS ONE 2013, 8, e61537. [CrossRef] [PubMed]

153. Zhang, Y.; Li, M.X.; Wang, H.; Zeng, Z.; Li, X.M. Metformin down-regulates endometrial carcinoma cell secretion of IGF-1 and expression of IGF-1R. Asian Pac. J. Cancer Prev. 2015, 16, 221-225. [CrossRef] [PubMed]

154. Abo-Elmatty, D.M.; Ahmed, E.A.; Tawfik, M.K.; Helmy, S.A. Metformin enhancing the antitumor efficacy of carboplatin against Ehrlich solid carcinoma grown in diabetic mice: Effect on IGF-1 and tumoral expression of IGF-1 receptors. Int. Immunopharmacol. 2017, 44, 72-86. [CrossRef] [PubMed]

155. Karnewar, S.; Neeli, P.K.; Panuganti, D.; Kotagiri, S.; Mallappa, S.; Jain, N.; Jerald, M.K.; Kotamraju, S. Metformin regulates mitochondrial biogenesis and senescence through AMPK mediated H3K79 methylation: Relevance in age-associated vascular dysfunction. Biochim. Biophys. Acta Mol. Basis Dis. 2018, 1864, 1115-1128. [CrossRef] [PubMed]

156. Kuang, Y.; Hu, B.; Feng, G.; Xiang, M.; Deng, Y.; Tan, M.; Li, J.; Song, J. Metformin prevents against oxidative stress-induced senescence in human periodontal ligament cells. Biogerontology 2020, 21, 13-27. [CrossRef]

157. Dodds, S.G.; Livi, C.B.; Parihar, M.; Hsu, H.K.; Benavides, A.D.; Morris, J.; Javors, M.; Strong, R.; Christy, B.; Hasty, P.; et al. Adaptations to chronic rapamycin in mice. Pathobiol. Aging Age Relat. Dis. 2016, 6, 31688. [CrossRef]

158. Swindell, W.R. Rapamycin in mice. Aging 2017, 9, 1941-1942. [CrossRef]

159. Blagosklonny, M.V. Fasting and rapamycin: Diabetes versus benevolent glucose intolerance. Cell Death Dis. 2019, 10, 607. [CrossRef]

160. Papadopoli, D.; Boulay, K.; Kazak, L.; Pollak, M.; Mallette, F.; Topisirovic, I.; Hulea, L. mTOR as a central regulator of lifespan and aging. F1000Research 2019, 8. [CrossRef]

161. Liu, Y.C.; Gao, X.X.; Zhang, Z.G.; Lin, Z.H.; Zou, Q.L. PPAR Gamma Coactivator 1 Beta (PGC-1beta) Reduces Mammalian Target of Rapamycin (mTOR) Expression via a SIRT1-Dependent Mechanism in Neurons. Cell. Mol. Neurobiol. 2017, 37, 879-887. [CrossRef]

162. Zhu, X.; Chu, H.; Jiang, S.; Liu, Q.; Liu, L.; Xue, Y.; Zheng, S.; Wan, W.; Qiu, J.; Wang, J.; et al. Sirt1 ameliorates systemic sclerosis by targeting the mTOR pathway. J. Dermatol. Sci. 2017, 87, 149-158. [CrossRef] [PubMed] 
163. Tokunaga, C.; Yoshino, K.; Yonezawa, K. mTOR integrates amino acid- and energy-sensing pathways. Biochem. Biophys. Res. Commun. 2004, 313, 443-446. [CrossRef] [PubMed]

164. Salminen, A.; Kaarniranta, K. Regulation of the aging process by autophagy. Trends Mol. Med. 2009, 15, 217-224. [CrossRef] [PubMed]

165. Kim, Y.C.; Guan, K.L. mTOR: A pharmacologic target for autophagy regulation. J. Clin. Investig. 2015, 125, 25-32. [CrossRef]

166. Munson, M.J.; Ganley, I.G. MTOR, PIK3C3, and autophagy: Signaling the beginning from the end. Autophagy 2015, 11, 2375-2376. [CrossRef]

167. Dall, K.B.; Faergeman, N.J. Metabolic regulation of lifespan from a C. elegans perspective. Genes Nutr. 2019, 14, 25. [CrossRef]

168. Kapahi, P.; Zid, B.M.; Harper, T.; Koslover, D.; Sapin, V.; Benzer, S. Regulation of lifespan in Drosophila by modulation of genes in the TOR signaling pathway. Curr. Biol. 2004, 14, 885-890. [CrossRef]

169. Kaeberlein, M.; Powers, R.W., 3rd; Steffen, K.K.; Westman, E.A.; Hu, D.; Dang, N.; Kerr, E.O.; Kirkland, K.T.; Fields, S.; Kennedy, B.K. Regulation of yeast replicative life span by TOR and Sch9 in response to nutrients. Science 2005, 310, 1193-1196. [CrossRef]

170. Lamming, D.W.; Ye, L.; Katajisto, P.; Goncalves, M.D.; Saitoh, M.; Stevens, D.M.; Davis, J.G.; Salmon, A.B.; Richardson, A.; Ahima, R.S.; et al. Rapamycin-induced insulin resistance is mediated by mTORC2 loss and uncoupled from longevity. Science 2012, 335, 1638-1643. [CrossRef]

171. Wu, J.J.; Liu, J.; Chen, E.B.; Wang, J.J.; Cao, L.; Narayan, N.; Fergusson, M.M.; Rovira, I.I.; Allen, M.; Springer, D.A.; et al. Increased mammalian lifespan and a segmental and tissue-specific slowing of aging after genetic reduction of mTOR expression. Cell Rep. 2013, 4, 913-920. [CrossRef]

172. Li, J.; Zhao, R.; Zhao, H.; Chen, G.; Jiang, Y.; Lyu, X.; Wu, T. Reduction of Aging-Induced Oxidative Stress and Activation of Autophagy by Bilberry Anthocyanin Supplementation via the AMPK-mTOR Signaling Pathway in Aged Female Rats. J. Agric. Food Chem. 2019, 67, 7832-7843. [CrossRef] [PubMed]

173. Di Francesco, A.; Diaz-Ruiz, A.; de Cabo, R.; Bernier, M. Intermittent mTOR Inhibition Reverses Kidney Aging in Old Rats. J. Gerontol. Ser. A Biol. Sci. Med Sci. 2018, 73, 843-844. [CrossRef] [PubMed]

174. Wang, Y.; Li, X.; He, Z.; Chen, W.; Lu, J. Rapamycin attenuates palmitate-induced lipid aggregation by up-regulating sirt-1 signaling in AML12 hepatocytes. Die Pharm. 2016, 71, 733-737. [CrossRef]

175. Fang, Y.; Hill, C.M.; Darcy, J.; Reyes-Ordonez, A.; Arauz, E.; McFadden, S.; Zhang, C.; Osland, J.; Gao, J.; Zhang, T.; et al. Effects of rapamycin on growth hormone receptor knockout mice. Proc. Natl. Acad. Sci. USA 2018, 115, E1495-E1503. [CrossRef] [PubMed]

176. Krebs, M.; Brunmair, B.; Brehm, A.; Artwohl, M.; Szendroedi, J.; Nowotny, P.; Roth, E.; Furnsinn, C.; Promintzer, M.; Anderwald, C.; et al. The Mammalian target of rapamycin pathway regulates nutrient-sensitive glucose uptake in man. Diabetes 2007, 56, 1600-1607. [CrossRef] [PubMed]

177. Ueno, M.; Carvalheira, J.B.; Tambascia, R.C.; Bezerra, R.M.; Amaral, M.E.; Carneiro, E.M.; Folli, F.; Franchini, K.G.; Saad, M.J. Regulation of insulin signalling by hyperinsulinaemia: Role of IRS-1/2 serine phosphorylation and the mTOR/p70 S6K pathway. Diabetologia 2005, 48, 506-518. [CrossRef]

178. Zhou, W.; Ye, S. Rapamycin improves insulin resistance and hepatic steatosis in type 2 diabetes rats through activation of autophagy. Cell Biol. Int. 2018, 42, 1282-1291. [CrossRef]

179. He, S.; Zhang, Y.; Wang, D.; Tao, K.; Zhang, S.; Wei, L.; Chen, Q. Rapamycin/GABA combination treatment ameliorates diabetes in NOD mice. Mol. Immunol. 2016, 73, 130-137. [CrossRef]

180. Reifsnyder, P.C.; Flurkey, K.; Te, A.; Harrison, D.E. Rapamycin treatment benefits glucose metabolism in mouse models of type 2 diabetes. Aging 2016, 8, 3120-3130. [CrossRef]

181. Garcia, D.N.; Saccon, T.D.; Pradiee, J.; Rincon, J.A.A.; Andrade, K.R.S.; Rovani, M.T.; Mondadori, R.G.; Cruz, L.A.X.; Barros, C.C.; Masternak, M.M.; et al. Effect of caloric restriction and rapamycin on ovarian aging in mice. Geroscience 2019, 41, 395-408. [CrossRef]

182. Laberge, R.M.; Sun, Y.; Orjalo, A.V.; Patil, C.K.; Freund, A.; Zhou, L.; Curran, S.C.; Davalos, A.R.; Wilson-Edell, K.A.; Liu, S.; et al. MTOR regulates the pro-tumorigenic senescence-associated secretory phenotype by promoting IL1A translation. Nat. Cell Biol. 2015, 17, 1049-1061. [CrossRef] [PubMed]

183. Horvath, S.; Lu, A.T.; Cohen, H.; Raj, K. Rapamycin retards epigenetic ageing of keratinocytes independently of its effects on replicative senescence, proliferation and differentiation. Aging (Albany NY) 2019, 11, 3238-3249. [CrossRef] [PubMed] 
184. Bishop-Bailey, D. Peroxisome proliferator-activated receptors in the cardiovascular system. Br. J. Pharmacol. 2000, 129, 823-834. [CrossRef] [PubMed]

185. Gross, B.; Pawlak, M.; Lefebvre, P.; Staels, B. PPARs in obesity-induced T2DM, dyslipidaemia and NAFLD. Nat. Rev. Endocrinol. 2017, 13, 36-49. [CrossRef] [PubMed]

186. Jay, M.A.; Ren, J. Peroxisome proliferator-activated receptor (PPAR) in metabolic syndrome and type 2 diabetes mellitus. Curr. Diabetes Rev. 2007, 3, 33-39. [CrossRef] [PubMed]

187. Kersten, S.; Desvergne, B.; Wahli, W. Roles of PPARs in health and disease. Nature 2000, 405, 421-424. [CrossRef] [PubMed]

188. Mansour, M. The roles of peroxisome proliferator-activated receptors in the metabolic syndrome. Prog. Mol. Biol. Transl. Sci. 2014, 121, 217-266. [CrossRef]

189. Hamilton-Craig, I.; Kostner, K.M.; Woodhouse, S.; Colquhoun, D. Use of fibrates in clinical practice: Queensland Lipid Group consensus recommendations. Int. J. Evid. Based Healthc. 2012, 10, 181-190. [CrossRef]

190. Hong, Y.A.; Lim, J.H.; Kim, M.Y.; Kim, T.W.; Kim, Y.; Yang, K.S.; Park, H.S.; Choi, S.R.; Chung, S.; Kim, H.W.; et al. Fenofibrate improves renal lipotoxicity through activation of AMPK-PGC-1alpha in $\mathrm{db} / \mathrm{db}$ mice. PLOS ONE 2014, 9, e96147. [CrossRef]

191. Kim, E.N.; Lim, J.H.; Kim, M.Y.; Kim, H.W.; Park, C.W.; Chang, Y.S.; Choi, B.S. PPARalpha agonist, fenofibrate, ameliorates age-related renal injury. Exp. Gerontol. 2016, 81, 42-50. [CrossRef]

192. Bojic, L.A.; Huff, M.W. Peroxisome proliferator-activated receptor delta: A multifaceted metabolic player. Curr. Opin. Lipidol. 2013, 24, 171-177. [CrossRef] [PubMed]

193. Ding, Y.; Yang, K.D.; Yang, Q. The role of PPARdelta signaling in the cardiovascular system. Prog. Mol. Biol. Transl. Sci. 2014, 121, 451-473. [CrossRef] [PubMed]

194. Vazquez-Carrera, M. Unraveling the Effects of PPARbeta/delta on Insulin Resistance and Cardiovascular Disease. Trends Endocrinol. Metab. 2016, 27, 319-334. [CrossRef]

195. Rizos, C.V.; Kei, A.; Elisaf, M.S. The current role of thiazolidinediones in diabetes management. Arch. Toxicol. 2016, 90, 1861-1881. [CrossRef]

196. Yki-Jarvinen, H. Thiazolidinediones. N. Engl. J. Med. 2004, 351, 1106-1118. [CrossRef]

197. Barbieri, M.; Bonafe, M.; Rizzo, M.R.; Ragno, E.; Olivieri, F.; Marchegiani, F.; Franceschi, C.; Paolisso, G. Gender specific association of genetic variation in peroxisome proliferator-activated receptor (PPAR)gamma-2 with longevity. Exp. Gerontol. 2004, 39, 1095-1100. [CrossRef]

198. Yang, H.C.; Deleuze, S.; Zuo, Y.; Potthoff, S.A.; Ma, L.J.; Fogo, A.B. The PPARgamma agonist pioglitazone ameliorates aging-related progressive renal injury. J. Am. Soc. Nephrol. 2009, 20, 2380-2388. [CrossRef]

199. Patel, H.; Giri, P.; Patel, P.; Singh, S.; Gupta, L.; Patel, U.; Modi, N.; Shah, K.; Jain, M.R.; Srinivas, N.R.; et al. Preclinical evaluation of saroglitazar magnesium, a dual PPAR-alpha/gamma agonist for treatment of dyslipidemia and metabolic disorders. Xenobiotica 2018, 48, 1268-1277. [CrossRef]

200. Patel, M.R.; Kansagra, K.A.; Parikh, D.P.; Parmar, D.V.; Patel, H.B.; Soni, M.M.; Patil, U.S.; Patel, H.V.; Patel, J.A.; Gujarathi, S.S.; et al. Effect of Food on the Pharmacokinetics of Saroglitazar Magnesium, a Novel Dual PPARalphagamma Agonist, in Healthy Adult Subjects. Clin. Drug Investig. 2018, 38, 57-65. [CrossRef]

201. Kaul, U.; Parmar, D.; Manjunath, K.; Shah, M.; Parmar, K.; Patil, K.P.; Jaiswal, A. New dual peroxisome proliferator activated receptor agonist-Saroglitazar in diabetic dyslipidemia and non-alcoholic fatty liver disease: Integrated analysis of the real world evidence. Cardiovasc. Diabetol. 2019, 18, 80. [CrossRef]

202. Xu, H.R.; Zhang, J.W.; Chen, W.L.; Ning, Z.Q.; Li, X.N. Pharmacokinetics, Safety and Tolerability of Chiglitazar, A Novel Peroxisome Proliferator-Activated Receptor (PPAR) Pan-Agonist, in Healthy Chinese Volunteers: A Phase I Study. Clin. Drug Investig. 2019, 39, 553-563. [CrossRef] [PubMed]

203. Park, M.H.; Kim, D.H.; Kim, M.J.; Lee, E.K.; An, H.J.; Jeong, J.W.; Kim, H.R.; Kim, S.J.; Yu, B.P.; Moon, H.R.; et al. Effects of MHY908, a New Synthetic PPARalpha/gamma Dual Agonist, on Inflammatory Responses and Insulin Resistance in Aged Rats. J. Gerontol. A Biol. Sci. Med. Sci. 2016, 71, 300-309. [CrossRef] [PubMed]

204. Wang, Z.; Gao, J.; Ohno, Y.; Liu, H.; Xu, C. Rosiglitazone ameliorates senescence and promotes apoptosis in ovarian cancer induced by olaparib. Cancer Chemother. Pharmacol. 2020, 1-12. [CrossRef] [PubMed]

205. Veech, R.L.; Chance, B.; Kashiwaya, Y.; Lardy, H.A.; Cahill, G.F., Jr. Ketone bodies, potential therapeutic uses. IUBMB Life 2001, 51, 241-247. [CrossRef] [PubMed]

206. Heitmann, R.N.; Dawes, D.J.; Sensenig, S.C. Hepatic ketogenesis and peripheral ketone body utilization in the ruminant. J. Nutr. 1987, 117, 1174-1180. [CrossRef] [PubMed] 
207. Cahill, G.F., Jr.; Herrera, M.G.; Morgan, A.P.; Soeldner, J.S.; Steinke, J.; Levy, P.L.; Reichard, G.A., Jr.; Kipnis, D.M. Hormone-fuel interrelationships during fasting. J. Clin. Investig. 1966, 45, 1751-1769. [CrossRef] [PubMed]

208. Hegardt, F.G. Mitochondrial 3-hydroxy-3-methylglutaryl-CoA synthase: A control enzyme in ketogenesis. Biochem. J. 1999, 338, 569-582. [CrossRef]

209. Shimazu, T.; Hirschey, M.D.; Newman, J.; He, W.; Shirakawa, K.; Le Moan, N.; Grueter, C.A.; Lim, H.; Saunders, L.R.; Stevens, R.D.; et al. Suppression of oxidative stress by beta-hydroxybutyrate, an endogenous histone deacetylase inhibitor. Science 2013, 339, 211-214. [CrossRef]

210. Bae, H.R.; Kim, D.H.; Park, M.H.; Lee, B.; Kim, M.J.; Lee, E.K.; Chung, K.W.; Kim, S.M.; Im, D.S.; Chung, H.Y. beta-Hydroxybutyrate suppresses inflammasome formation by ameliorating endoplasmic reticulum stress via AMPK activation. Oncotarget 2016, 7, 66444-66454. [CrossRef]

211. Maalouf, M.; Sullivan, P.G.; Davis, L.; Kim, D.Y.; Rho, J.M. Ketones inhibit mitochondrial production of reactive oxygen species production following glutamate excitotoxicity by increasing NADH oxidation. Neuroscience 2007, 145, 256-264. [CrossRef]

212. Newman, J.C.; Verdin, E. Ketone bodies as signaling metabolites. Trends Endocrinol. Metab. 2014, 25, 42-52. [CrossRef] [PubMed]

213. Kinzig, K.P.; Honors, M.A.; Hargrave, S.L. Insulin sensitivity and glucose tolerance are altered by maintenance on a ketogenic diet. Endocrinology 2010, 151, 3105-3114. [CrossRef] [PubMed]

214. Garbow, J.R.; Doherty, J.M.; Schugar, R.C.; Travers, S.; Weber, M.L.; Wentz, A.E.; Ezenwajiaku, N.; Cotter, D.G.; Brunt, E.M.; Crawford, P.A. Hepatic steatosis, inflammation, and ER stress in mice maintained long term on a very low-carbohydrate ketogenic diet. Am. J. Physiol. Gastrointest. Liver Physiol. 2011, 300, G956-G967. [CrossRef] [PubMed]

215. McDaniel, S.S.; Rensing, N.R.; Thio, L.L.; Yamada, K.A.; Wong, M. The ketogenic diet inhibits the mammalian target of rapamycin (mTOR) pathway. Epilepsia 2011, 52, e7-e11. [CrossRef]

216. Kennedy, A.R.; Pissios, P.; Otu, H.; Roberson, R.; Xue, B.; Asakura, K.; Furukawa, N.; Marino, F.E.; Liu, F.F.; Kahn, B.B.; et al. A high-fat, ketogenic diet induces a unique metabolic state in mice. Am. J. Physiol. Endocrinol. Metab. 2007, 292, E1724-E1739. [CrossRef]

217. Veech, R.L.; Bradshaw, P.C.; Clarke, K.; Curtis, W.; Pawlosky, R.; King, M.T. Ketone bodies mimic the life span extending properties of caloric restriction. IUBMB Life 2017, 69, 305-314. [CrossRef]

218. Kim, D.H.; Park, M.H.; Ha, S.; Bang, E.J.; Lee, Y.; Lee, A.K.; Lee, J.; Yu, B.P.; Chung, H.Y. Anti-inflammatory action of beta-hydroxybutyrate via modulation of PGC-1alpha and FoxO1, mimicking calorie restriction. Aging (Albany NY) 2019, 11, 1283-1304. [CrossRef]

219. Kimura, I.; Inoue, D.; Maeda, T.; Hara, T.; Ichimura, A.; Miyauchi, S.; Kobayashi, M.; Hirasawa, A.; Tsujimoto, G. Short-chain fatty acids and ketones directly regulate sympathetic nervous system via $G$ protein-coupled receptor 41 (GPR41). Proc. Natl. Acad. Sci. USA 2011, 108, 8030-8035. [CrossRef]

220. Tunaru, S.; Kero, J.; Schaub, A.; Wufka, C.; Blaukat, A.; Pfeffer, K.; Offermanns, S. PUMA-G and HM74 are receptors for nicotinic acid and mediate its anti-lipolytic effect. Nat. Med. 2003, 9, 352-355. [CrossRef]

221. Ahmed, K.; Tunaru, S.; Offermanns, S. GPR109A, GPR109B and GPR81, a family of hydroxy-carboxylic acid receptors. Trends Pharmacol. Sci. 2009, 30, 557-562. [CrossRef]

222. Fu, S.P.; Liu, B.R.; Wang, J.F.; Xue, W.J.; Liu, H.M.; Zeng, Y.L.; Huang, B.X.; Li, S.N.; Lv, Q.K.; Wang, W.; et al. beta-Hydroxybutyric acid inhibits growth hormone-releasing hormone synthesis and secretion through the GPR109A/extracellular signal-regulated 1/2 signalling pathway in the hypothalamus. J. Neuroendocrinol. 2015, 27, 212-222. [CrossRef] [PubMed]

223. Rahman, M.; Muhammad, S.; Khan, M.A.; Chen, H.; Ridder, D.A.; Muller-Fielitz, H.; Pokorna, B.; Vollbrandt, T.; Stolting, I.; Nadrowitz, R.; et al. The beta-hydroxybutyrate receptor HCA2 activates a neuroprotective subset of macrophages. Nat. Commun. 2014, 5, 3944. [CrossRef]

224. Fu, S.P.; Li, S.N.; Wang, J.F.; Li, Y.; Xie, S.S.; Xue, W.J.; Liu, H.M.; Huang, B.X.; Lv, Q.K.; Lei, L.C.; et al. BHBA suppresses LPS-induced inflammation in BV-2 cells by inhibiting NF-kappaB activation. Mediat. Inflamm. 2014, 2014, 983401. [CrossRef] [PubMed]

225. Gambhir, D.; Ananth, S.; Veeranan-Karmegam, R.; Elangovan, S.; Hester, S.; Jennings, E.; Offermanns, S.; Nussbaum, J.J.; Smith, S.B.; Thangaraju, M.; et al. GPR109A as an anti-inflammatory receptor in retinal pigment epithelial cells and its relevance to diabetic retinopathy. Investig. Ophthalmol. Vis. Sci. 2012, 53, 2208-2217. [CrossRef] [PubMed] 
226. Puchalska, P.; Crawford, P.A. Multi-dimensional Roles of Ketone Bodies in Fuel Metabolism, Signaling, and Therapeutics. Cell Metab. 2017, 25, 262-284. [CrossRef]

227. Bang, E.; Lee, B.; Noh, S.G.; Kim, D.H.; Jung, H.J.; Ha, S.; Yu, B.P.; Chung, H.Y. Modulation of senoinflammation by calorie restriction based on biochemical and Omics big data analysis. BMB Rep. 2019, 52, 56-63. [CrossRef]

228. Park, H.S.; Nam, H.S.; Seo, H.S.; Hwang, S.J. Change of periodontal inflammatory indicators through a 4-week weight control intervention including caloric restriction and exercise training in young Koreans: A pilot study. BMC Oral Health 2015, 15, 109. [CrossRef]

229. Youm, Y.H.; Nguyen, K.Y.; Grant, R.W.; Goldberg, E.L.; Bodogai, M.; Kim, D.; D'Agostino, D.; Planavsky, N.; Lupfer, C.; Kanneganti, T.D.; et al. The ketone metabolite beta-hydroxybutyrate blocks NLRP3 inflammasome-mediated inflammatory disease. Nat. Med. 2015, 21, 263-269. [CrossRef]

230. Wang, J.; Vanegas, S.M.; Du, X.; Noble, T.; Zingg, J.M.; Meydani, M.; Meydani, S.N.; Wu, D. Caloric restriction favorably impacts metabolic and immune/inflammatory profiles in obese mice but curcumin/piperine consumption adds no further benefit. Nutr. Metab. 2013, 10, 29. [CrossRef]

231. Yamada, K.; Takizawa, S.; Ohgaku, Y.; Asami, T.; Furuya, K.; Yamamoto, K.; Takahashi, F.; Hamajima, C.; Inaba, C.; Endo, K.; et al. MicroRNA 16-5p is upregulated in calorie-restricted mice and modulates inflammatory cytokines of macrophages. Gene 2020, 725, 144191. [CrossRef]

232. Su, H.Y.; Lee, H.C.; Cheng, W.Y.; Huang, S.Y. A calorie-restriction diet supplemented with fish oil and high-protein powder is associated with reduced severity of metabolic syndrome in obese women. Eur. J. Clin. Nutr. 2015, 69, 322-328. [CrossRef] [PubMed]

233. Willette, A.A.; Bendlin, B.B.; McLaren, D.G.; Canu, E.; Kastman, E.K.; Kosmatka, K.J.; Xu, G.; Field, A.S.; Alexander, A.L.; Colman, R.J.; et al. Age-related changes in neural volume and microstructure associated with interleukin-6 are ameliorated by a calorie-restricted diet in old rhesus monkeys. Neuroimage 2010, 51, 987-994. [CrossRef] [PubMed]

234. Das, U.N. A defect in the activity of Delta6 and Delta5 desaturases may be a factor predisposing to the development of insulin resistance syndrome. Prostaglandins Leukot Essent Fat. Acids 2005, 72, 343-350. [CrossRef] [PubMed]

235. Willette, A.A.; Coe, C.L.; Birdsill, A.C.; Bendlin, B.B.; Colman, R.J.; Alexander, A.L.; Allison, D.B.; Weindruch, R.H.; Johnson, S.C. Interleukin-8 and interleukin-10, brain volume and microstructure, and the influence of calorie restriction in old rhesus macaques. Age 2013, 35, 2215-2227. [CrossRef] [PubMed]

236. Liu, B.; Page, A.J.; Hatzinikolas, G.; Chen, M.; Wittert, G.A.; Heilbronn, L.K. Intermittent Fasting Improves Glucose Tolerance and Promotes Adipose Tissue Remodeling in Male Mice Fed a High-Fat Diet. Endocrinology 2019, 160, 169-180. [CrossRef]

237. Sharov, A.A.; Falco, G.; Piao, Y.; Poosala, S.; Becker, K.G.; Zonderman, A.B.; Longo, D.L.; Schlessinger, D.; Ko, M. Effects of aging and calorie restriction on the global gene expression profiles of mouse testis and ovary. BMC Biol. 2008, 6, 24. [CrossRef]

238. Chen, J.; Mo, R.; Lescure, P.A.; Misek, D.E.; Hanash, S.; Rochford, R.; Hobbs, M.; Yung, R.L. Aging is associated with increased T-cell chemokine expression in C57BL/6 mice. J. Gerontol. A Biol. Sci. Med. Sci. 2003, 58, 975-983. [CrossRef]

239. Babu, H.; Ambikan, A.T.; Gabriel, E.E.; Svensson Akusjarvi, S.; Palaniappan, A.N.; Sundaraj, V.; Mupanni, N.R.; Sperk, M.; Cheedarla, N.; Sridhar, R.; et al. Systemic Inflammation and the Increased Risk of Inflamm-Aging and Age-Associated Diseases in People Living With HIV on Long Term Suppressive Antiretroviral Therapy. Front. Immunol. 2019, 10, 1965. [CrossRef]

240. Lan, C.E.; Hung, Y.T.; Fang, A.H.; Ching-Shuang, W. Effects of irradiance on UVA-induced skin aging. J. Dermatol. Sci. 2019, 94, 220-228. [CrossRef]

241. Wang, M.; Zhang, L.; Zhu, W.; Zhang, J.; Kim, S.H.; Wang, Y.; Ni, L.; Telljohann, R.; Monticone, R.E.; McGraw, K.; et al. Calorie Restriction Curbs Proinflammation That Accompanies Arterial Aging, Preserving a Youthful Phenotype. J. Am. Heart Assoc. 2018, 7, e009112. [CrossRef]

242. Caria, C.; Gotardo, E.M.F.; Santos, P.S.; Acedo, S.C.; de Morais, T.R.; Ribeiro, M.L.; Gambero, A. Extracellular matrix remodeling and matrix metalloproteinase inhibition in visceral adipose during weight cycling in mice. Exp. Cell Res. 2017, 359, 431-440. [CrossRef] [PubMed]

243. Varani, J.; Bhagavathula, N.; Aslam, M.N.; Fay, K.; Warner, R.L.; Hanosh, A.; Barron, A.G.; Miller, R.A. Inhibition of retinoic acid-induced skin irritation in calorie-restricted mice. Arch. Dermatol. Res. 2008, 300, 27-35. [CrossRef] [PubMed] 
244. Wiggins, J.E.; Patel, S.R.; Shedden, K.A.; Goyal, M.; Wharram, B.L.; Martini, S.; Kretzler, M.; Wiggins, R.C. NFkappaB promotes inflammation, coagulation, and fibrosis in the aging glomerulus. J. Am. Soc. Nephrol. 2010, 21, 587-597. [CrossRef] [PubMed]

245. Kim, H.J.; Jung, K.J.; Seo, A.Y.; Choi, J.S.; Yu, B.P.; Chung, H.Y. Calorie restriction modulates redox-sensitive AP-1 during the aging process. J. Am. Aging Assoc. 2002, 25, 123-130. [CrossRef] [PubMed]

246. Reddy Avula, C.P.; Lawrence, R.A.; Zaman, K.; Fernandes, G. Inhibition of intracellular peroxides and apoptosis of lymphocytes in lupus-prone B/W mice by dietary n-6 and n-3 lipids with calorie restriction. J. Clin. Immunol. 2002, 22, 206-219. [CrossRef] [PubMed]

247. Lin, Y.Y.; Hsieh, P.S.; Cheng, Y.J.; Cheng, S.M.; Chen, C.J.; Huang, C.Y.; Kuo, C.H.; Kao, C.L.; Shyu, W.C.; Lee, S.D. Anti-apoptotic and Pro-survival Effects of Food Restriction on High-Fat Diet-Induced Obese Hearts. Cardiovasc. Toxicol. 2017, 17, 163-174. [CrossRef]

248. Ando, K.; Higami, Y.; Tsuchiya, T.; Kanematsu, T.; Shimokawa, I. Impact of aging and life-long calorie restriction on expression of apoptosis-related genes in male F344 rat liver. Microsc. Res. Tech. 2002, 59, 293-300. [CrossRef]

249. Nylen, C.; Lundell, L.S.; Massart, J.; Zierath, J.R.; Naslund, E. Short-term low-calorie diet remodels skeletal muscle lipid profile and metabolic gene expression in obese adults. Am. J. Physiol. Endocrinol. Metab. 2019, 316, E178-E185. [CrossRef]

250. Palee, S.; Minta, W.; Mantor, D.; Sutham, W.; Jaiwongkam, T.; Kerdphoo, S.; Pratchayasakul, W.; Chattipakorn, S.C.; Chattipakorn, N. Combination of exercise and calorie restriction exerts greater efficacy on cardioprotection than monotherapy in obese-insulin resistant rats through the improvement of cardiac calcium regulation. Metabolism 2019, 94, 77-87. [CrossRef]

251. Kim, D.H.; Park, M.H.; Lee, E.K.; Choi, Y.J.; Chung, K.W.; Moon, K.M.; Kim, M.J.; An, H.J.; Park, J.W.; Kim, N.D.; et al. The roles of FoxOs in modulation of aging by calorie restriction. Biogerontology 2015, 16, 1-14. [CrossRef]

252. Lopez-Domenech, S.; Abad-Jimenez, Z.; Iannantuoni, F.; de Maranon, A.M.; Rovira-Llopis, S.; Morillas, C.; Banuls, C.; Victor, V.M.; Rocha, M. Moderate weight loss attenuates chronic endoplasmic reticulum stress and mitochondrial dysfunction in human obesity. Mol. Metab. 2019, 19, 24-33. [CrossRef]

253. Kim, G.W.; Lin, J.E.; Snook, A.E.; Aing, A.S.; Merlino, D.J.; Li, P.; Waldman, S.A. Calorie-induced ER stress suppresses uroguanylin satiety signaling in diet-induced obesity. Nutr. Diabetes 2016, 6, e211. [CrossRef] [PubMed]

254. Ding, S.; Jiang, J.; Zhang, G.; Bu, Y.; Zhang, G.; Zhao, X. Resveratrol and caloric restriction prevent hepatic steatosis by regulating SIRT1-autophagy pathway and alleviating endoplasmic reticulum stress in high-fat diet-fed rats. PLoS ONE 2017, 12, e0183541. [CrossRef]

255. Walters, R.O.; Arias, E.; Diaz, A.; Burgos, E.S.; Guan, F.; Tiano, S.; Mao, K.; Green, C.L.; Qiu, Y.; Shah, H.; et al. Sarcosine Is Uniquely Modulated by Aging and Dietary Restriction in Rodents and Humans. Cell Rep. 2018, 25, 663-676.e666. [CrossRef] [PubMed]

256. Gregosa, A.; Vinuesa, A.; Todero, M.F.; Pomilio, C.; Rossi, S.P.; Bentivegna, M.; Presa, J.; Wenker, S.; Saravia, F.; Beauquis, J. Periodic dietary restriction ameliorates amyloid pathology and cognitive impairment in PDAPP-J20 mice: Potential implication of glial autophagy. Neurobiol. Dis. 2019, 132, 104542. [CrossRef]

257. Devarajan, A.; Rajasekaran, N.S.; Valburg, C.; Ganapathy, E.; Bindra, S.; Freije, W.A. Maternal perinatal calorie restriction temporally regulates the hepatic autophagy and redox status in male rat. Free Radic. Biol. Med. 2019, 130, 592-600. [CrossRef]

258. Marino, G.; Pietrocola, F.; Madeo, F.; Kroemer, G. Caloric restriction mimetics: Natural/physiological pharmacological autophagy inducers. Autophagy 2014, 10, 1879-1882. [CrossRef]

259. van Eyk, H.J.; van Schinkel, L.D.; Kantae, V.; Dronkers, C.E.A.; Westenberg, J.J.M.; de Roos, A.; Lamb, H.J.; Jukema, J.W.; Harms, A.C.; Hankemeier, T.; et al. Caloric restriction lowers endocannabinoid tonus and improves cardiac function in type 2 diabetes. Nutr. Diabetes 2018, 8, 6. [CrossRef]

260. Wang, S.; Huang, M.; You, X.; Zhao, J.; Chen, L.; Wang, L.; Luo, Y.; Chen, Y. Gut microbiota mediates the anti-obesity effect of calorie restriction in mice. Sci. Rep. 2018, 8, 13037. [CrossRef] [PubMed] 
261. Chung, K.W.; Lee, E.K.; Lee, M.K.; Oh, G.T.; Yu, B.P.; Chung, H.Y. Impairment of PPARalpha and the Fatty Acid Oxidation Pathway Aggravates Renal Fibrosis during Aging. J. Am. Soc. Nephrol. 2018, 29, 1223-1237. [CrossRef]

262. Kim, J.Y.; Kim, D.H.; Choi, J.; Park, J.K.; Jeong, K.S.; Leeuwenburgh, C.; Yu, B.P.; Chung, H.Y. Changes in lipid distribution during aging and its modulation by calorie restriction. Age 2009, 31, 127-142. [CrossRef] [PubMed]

(C) 2020 by the authors. Licensee MDPI, Basel, Switzerland. This article is an open access article distributed under the terms and conditions of the Creative Commons Attribution (CC BY) license (http://creativecommons.org/licenses/by/4.0/). 